\title{
Sodium Channel Blockers for the Treatment of Neuropathic Pain
}

\author{
Anindya Bhattacharya, Alan D. Wickenden, and Sandra R. Chaplan \\ Pain \& Related Disorders Team, Johnson \& Johnson Pharmaceutical Research \& Development, LLC, San Diego, \\ California 92121
}

Summary: Drugs that block voltage-gated sodium channels are efficacious in the management of neuropathic pain. Accordingly, this class of ion channels has been a major focus of analgesic research both in academia and in the pharmaceutical/biotechnology industry. In this article, we review the history of the use of sodium channel blockers, describe the current status of sodium channel drug discovery, highlight the challenges and hurdles to attain sodium channel subtype selectivity, and review the potential usefulness of selective sodium channel blockers in neuropathic pain. Key Words: Sodium channel, subtype, selectivity, neuropathic pain, drug discovery.

\section{HISTORY OF THE USE OF SYSTEMIC SODIUM CHANNEL BLOCKERS FOR PAIN}

The current appreciation of the use of sodium channel blockers in the treatment of neuropathic pain represents the convergence of a number of separate advances in scientific understanding. Pharmacological distinctions between acute and chronic pain could not be made until drugs with relevant yet pharmacologically different actions were created. Trigeminal neuralgia was described as early as the first century $A D$, but the consequences of injuries to other peripheral nerves were not formally recognized until the American Civil War, ${ }^{1}$ and a general concept of neuropathic pain did not emerge until more than a century later. Improvements in electrophysiological recording techniques led to the ability to study the role of sodium channel blockers in the treatment of electrophysiological disorders with manifestations as different as cardiac arrhythmias, epilepsy, and neuropathic pain. Confirming neuropathic pain as an electrophysiological disorder required experimental observations from patients and adequate preclinical experimental models.

Address correspondence and reprint requests to: Sandra R. Chaplan M.D., Pain \& Related Disorders Team, Johnson \& Johnson Pharmaceutical Research \& Development, LLC, 3210 Merryfield Row, San Diego, CA 92121. E-mail: schaplan@its.jnj.com.
The history of the use of sodium channel blockers as analgesics considerably predates any modern understanding of the role of ion channels in pain. Use of the coca plant for its invigorating powers was known at least 3,000 years ago, based on radiocarbon dating of Andean mummies containing traces of a stable cocaine metabolite. ${ }^{2}$ Systemic use of coca was likely based primarily on its stimulatory, dopamine transporter-blocking properties, rather than its local anesthetic, sodium channel blocking properties, but topical use is presumed as well. ${ }^{3}$ Widespread European use of cocaine was first enabled by the extraction of pure cocaine from the perishable coca leaves by Gaedcke ${ }^{4}$ in 1855 , whereupon its uptake into medicinal and other forms of use was rapid. Both Sigmund Freud and Carl Koller have been credited with recognizing the usefulness of cocaine as a topical anesthetic for surgical use in $1884 .^{5}$ The first recorded treatment of neuropathic pain with a sodium channel blocker is probably Freud's treatment of Ernst von Fleischl, who suffered from trigeminal neuralgia, with cocaine injections. ${ }^{6}$ The evident toxic liabilities of cocaine soon led to medicinal chemistry efforts to find a safer compound with similar local anesthetic properties. ${ }^{7}$ To this end, Albert Einhorn synthesized procaine in 1904, leading the way for additional ester local anesthetics. Local anesthetics addressed an enormous unmet medical need for alternatives to early general anesthesia techniques, and these anesthetics were readily adopted for use in topical 
and spinal anesthesia, as well as regional nerve blockade and local infiltration.

Systemic infusion of local anesthetics for general anesthesia was also quite popular for many decades; procaine or lidocaine (synthesized by Nils Loefgren in 1943) was used alone or in combination with nitrous oxide. ${ }^{8,9}$ Although systemically administered local anesthetics were extremely useful in the surgical setting, studies revealed that they held less practical use as analgesics outside the operating room. In 1944, Bigelow and Harrison ${ }^{10}$ specifically explored procaine's analgesic dose-response by administering it subcutaneously to five conscious, un-anesthetized subjects. They recorded the resulting suppression of noxious radiant heat sensation, which they described as transient, and accompanied by sedation.

The treatment of trigeminal neuralgia with the anticonvulsant phenytoin (diphenylhydantoin, hydantoin, Dilantin [Parke-Davis]) was advocated in published literature as early as the $1950 \mathrm{~s} .{ }^{11}$ Of note, Kugelberg and Lindblom ${ }^{12}$ performed an unblinded study of the effects of intravenous lidocaine and phenytoin on trigeminal neuralgia attacks in 1959. Both agents showed efficacy, albeit short-lived. In 1962, efficacy of the new anticonvulsant carbamazepine (Tegretol [Novartis]) in trigeminal neuralgia patients was reported in the journal Lancet. ${ }^{13}$ These reports represented significant advances in the pharmacological management of trigeminal neuralgia for which primarily surgical or ablative options were previously available. Controlled studies of the use of sodium channel blocking anticonvulsants in neuropathic pain are listed in Table 1 .

Clinical recognition of a common mechanism of action of phenytoin, carbamazepine, and lidocaine came from a separate therapeutic context. In 1975, Vaughn Williams ${ }^{14}$ published a classification of the mechanisms of action of cardiac anti-arrhythmics into four groups, based on their electrophysiological effects. In this classification, lidocaine, which had gained currency by then as a treatment for cardiac ventricular dysrhythmias, was grouped with the anticonvulsants phenytoin and carbamazepine. ${ }^{15,16}$ These agents were assigned to Vaughn Williams class Ib, characterized by: "interfering specifically with the process by which depolarizing charge is transferred across the membrane (i.e., by fast inward current carried by sodium ions)." ${ }^{17}$ Thus, these three agents were all recognized as sodium channel blockers, all were known as anti-arrhythmics, and all had demonstrated efficacy in the suppression of the pain of trigeminal neuralgia.

Early studies characterizing abnormal electrical activity in pathways related to chronic pain states provided important support for a pharmacological approach explicitly aimed at suppressing these foci. Examples included a series of intraoperative extracellular recordings by Loeser ${ }^{18}$ from the spinal cord dorsal horn of an individ- ual with spinal cord injury resulting in chronic spontaneous neuropathic pain. Burst firing and spontaneous high-frequency firing, similar to patterns seen in cortical epileptic foci, were recorded from dorsal horn neurons. Burchiel and Wyler $^{19}$ recorded abnormal discharges from experimentally compressed feline trigeminal ganglia, which were suppressed by phenytoin. These and other similar studies helped to frame the treatment of abnormal pain states in the context of abnormal electrical activity.

Beginning in the early 1980 s, a series of studies using lidocaine and related local anesthetics brought both the problem of neuropathic pain and the therapeutic potential of sodium channel blockers into greater focus. In 1982, Boas et al. ${ }^{20}$ published an unblinded study of the analgesic effect of intravenous lidocaine in severe, chronic pain of neurological origin. A stated rationale for the study was the known use of lidocaine in reducing bursting electrical activity in brain and cardiac foci, along with the spinal cord and trigeminal recordings previously described. The five patients studied suffered from thalamic pain, trigeminal neuralgia, phantom pain, arachnoiditis, and post-rhizotomy pain. This study broke significant ground in proposing a common mechanistic basis for these disparate forms of refractory pain, and in proposing treatment of neuropathic pain explicitly based on suppression of an abnormally active electrophysiological focus. During the lidocaine infusion, four patients experienced profound reductions in pain scores. Importantly, the magnitude of the effect of lidocaine in these neuropathic pain states far exceeded previous results using lidocaine in acute or experimental pain states. This study inspired controlled studies of intravenous lidocaine in patients with a variety of neuropathic pain disorders and painful diabetic neuropathy. Following up on a small case series using lidocaine to treat the pain of Dercums' disease ${ }^{21}$ Kastrup et al. ${ }^{22}$ performed a controlled study in 1987 in patients suffering from painful diabetic neuropathy. Of note, in addition to significant differences between placebo and lidocaine treatment, the duration of relief from lidocaine infusion in this study ranged from 3 to 21 days, presumably outlasting the complete elimination of lidocaine. A host of subsequent studies with lidocaine or its analogs (see Table 1) have supported these positive findings. Confirmation of the efficacy of lidocaine in well-controlled trials brought attention to the mechanistic relevance of sodium channel blockade and also provided a meaningful therapeutic intervention for many patients.

The lack of oral bioavailability and low safety margin of lidocaine have remained constraints on its use, although it remains among the most consistently efficacious treatments for neuropathic pain. In 1987, Lindstrom and Lindblom ${ }^{23}$ conducted a double-blind crossover trial of the anti-arrhythmic tocainide (an orally bioavailable analog 
Table 1. Controlled Clinical Trials of Sodium Channel Blockers for Neuropathic Pain

\begin{tabular}{|c|c|c|c|c|}
\hline Agent & Condition & Result & Year & Ref. No. \\
\hline 4030W92 & Peripheral & NS & 2002 & 42 \\
\hline Amitriptyline & PHN & Pos & 1982 & 31 \\
\hline Amitriptyline/ & Central poststroke & Pos & & \\
\hline Carbamazepine & & Pos & 1989 & 32 \\
\hline Amitriptyline & Postmastectomy & Pos & 1996 & 166 \\
\hline Amitriptyline & Chemotherapy-induced & NS & 2008 & 167 \\
\hline Carbamazepine & Trigeminal neuralgia & Pos & 1966 & 168 \\
\hline Carbamazepine & Multiple & Mixed & 1968 & 169 \\
\hline Carbamazepine & PDN & Pos & 1969 & 170 \\
\hline Carbamazepine & CRPS & Pos & 2001 & 171 \\
\hline Desipramine & PHN & Pos & 1990 & 172 \\
\hline Desipramine & PDN & Pos & 1991 & 173 \\
\hline Duloxetine & PDN & Pos & 2005 & 174 \\
\hline Duloxetine & PDN & Pos & 2005 & 175 \\
\hline Duloxetine & PDN & Pos & 2006 & 176 \\
\hline Lacosamide & PDN & Pos & 2007 & 177 \\
\hline Lacosamide & PDN & Pos & 2009 & 178 \\
\hline Lacosamide & PDN & Pos & 2009 & 179 \\
\hline Lamotrigine & Trigeminal neuralgia & Pos & 1997 & 180 \\
\hline Lamotrigine & Various & NS & 1999 & 181 \\
\hline Lamotrigine & PDN & Pos & 2001 & 182 \\
\hline Lamotrigine & Central poststroke & Mixed & 2001 & 183 \\
\hline Lamotrigine & Spinal cord injury & Mixed & 2002 & 184 \\
\hline Lamotrigine & HIV-ART neuropathy & Pos & 2003 & 185 \\
\hline Lamotrigine & Chemotherapy-induced & NS & 2008 & 186 \\
\hline Lidocaine & PDN & Pos & 1989 & 187 \\
\hline Lidocaine & Cancer/treatment & NS & 1989 & 188 \\
\hline Lidocaine & PHN & Pos & 1991 & 189 \\
\hline Lidocaine & Malignant plexopathy & NS & 1992 & 190 \\
\hline Lidocaine & Sciatica & Pos & 1999 & 191 \\
\hline Lidocaine & CRPS I and II & Pos & 2000 & 192 \\
\hline Lidocaine & Central neuropathic & Pos & 2000 & 193 \\
\hline Lidocaine & Spinal cord injury & Pos & 2005 & 194 \\
\hline Lidocaine & Peripheral & Pos & 2006 & 195 \\
\hline Lidocaine & Central poststroke & Pos & 1992 & 196 \\
\hline Lidocaine & PHN, nerve trauma & Pos & 2004 & 197 \\
\hline Lidocaine/ & Multiple sclerosis & Pos & & \\
\hline Mexiletine & & Pos & 1999 & 198 \\
\hline Mexiletine & PDN & Pos & 1988 & 24 \\
\hline Mexiletine & Nerve injury & Pos & 1989 & 199 \\
\hline Mexiletine & Neuropathy & Pos & 1992 & 200 \\
\hline Mexiletine & PDN & NS & 1992 & 201 \\
\hline Mexiletine & Spinal cord injury & NS & 1996 & 202 \\
\hline Mexiletine & PDN & Pos & 1997 & 203 \\
\hline Mexiletine & PDN & NS & 1997 & 204 \\
\hline Mexiletine & Unspecified & NS & 2000 & 205 \\
\hline Oxcarbazepine & PDN & Pos & 2005 & 39 \\
\hline Oxcarbazepine & PDN & Pos & 2006 & 40 \\
\hline Phenytoin & PDN & NS & 1977 & 206 \\
\hline Phenytoin & PDN & Pos & 1978 & 207 \\
\hline Ralfinamide & Various & Pos & 2008 & $*$ \\
\hline Riluzole & Peripheral & NS & 2000 & 208 \\
\hline Tetrodotoxin & Cancer & Pos & 2008 & 43 \\
\hline
\end{tabular}

$\mathrm{ART}=$ antiretroviral therapy; CRPS $=$ complex regional pain syndrome; NS = not significant; PDN = painful diabetic neuropathy; PHN = postherpetic neuralgia; Pos $=$ positive.

Compilation of randomized, controlled trials of known sodium channel blocking agents in neuropathic pain states. This table is limited to studies whose methodology could be confirmed; access to some early literature was not possible. Inclusion of tricyclic antidepressants is limited to those demonstrated to have significant sodium channel blocking properties.

*http://www.newron.com/uploads/posterA3nocrop.pdf. 
of lidocaine developed as an anti-arrhythmic) and carbamazepine. They concluded that tocainide was highly effective in trigeminal neuralgia, and speculated that its mechanism was similar to carbamazepine. Due to safety concerns, however, there was little uptake of tocainide for use in pain treatment. In 1988, the publication of a positive study of mexiletine (another orally bioavailable analog of lidocaine) in diabetic neuropathy by Dejgard and colleagues ${ }^{24}$ created a furor of interest, and inspired numerous additional studies, because it offered the hope of an oral agent suitable for clinical use with efficacy similar to lidocaine. Studies have shown that sodium channel blockade contributes to the efficacy of another important category of drugs used to treat pain. Amitriptyline and other similar tricyclic antidepressants are among the more efficacious drugs in a variety of neuropathic pain states such as postherpetic neuralgia and central poststroke pain. ${ }^{25-27}$ Although the primary pharmacology of amitriptyline and other tricyclic antidepressants is monoamine reuptake inhibition, a clinically validated mechanism of action in neuropathic pain management in its own right, many tricyclics are also sodium channel blockers. In vitro, amitriptyline competes with lidocaine for a binding site on cardiac sodium channels and blocks brain sodium channels; in vivo, blockade of cardiac sodium channels contributes to its cardiotoxicity in overdose. ${ }^{28,29}$ Additional tricyclic antidepressants with efficacy in neuropathic pain exhibit similar secondary pharmacology (Table 1). ${ }^{30}$

Over the past two or three decades, the creation of preclinical models of nerve injury has provided an experimental basis for the study of neuropathic pain mechanisms. Early studies in axotomy models revealed that spontaneous firing developed after nerve injury. ${ }^{31}$ Major nerve injury models were subsequently developed in which motor function of the affected limb was spared, permitting the study of pain behavior as well as neuronal activity. These models, commonly known as the chronic constriction injury (or Bennett) model, ${ }^{32}$ the partial sciatic ligation (or Seltzer) model, ${ }^{33}$ and the L5/6 spinal nerve ligation (or Chung) model, ${ }^{34}$ enabled systematic laboratory investigations of neuropathic pain mechanisms and continue to be fundamentally important research tools. In 1988, Kajander et al. ${ }^{35}$ described the origin of abnormal neuronal discharges from the dorsal root ganglion (DRG) as well as the injury site of the chronically constricted rat sciatic nerve. In 1992, using the Seltzer model, Devor et al. ${ }^{36}$ reported that intravenous administration of lidocaine temporarily suppressed ectopic discharges from the DRG of the partially ligated rat sciatic nerve. The ability to correlate neuropathic pain states in these anatomically reproducible models with electrophysiological, histological, and molecular changes, has led to great progress in pain research.

\section{CLINICAL EXPERIENCE WITH NEWER SODIUM CHANNEL BLOCKERS IN NEUROPATHIC PAIN}

There continues to be a need for new, safer, more tolerable, and more efficacious neuropathic pain treatments. At this time, all currently available drugs with sodium channel blocking properties have tolerability limitations. Regardless of off-target adverse effects, the therapeutic margin for nonselective sodium channel blockade is narrow, and optimization of efficacy in pain may be at the expense of central nervous system liabilities, including seizures (due to blockade of inhibitory pathways), ataxia, confusion, and sedation. To maintain plasma concentrations within a therapeutic window, often drug level monitoring is necessary, necessitating medical follow-up and titration. Off-target adverse effects of these generally low potency drugs may be problematic as well. Phenytoin is associated with numerous adverse effects, including rash, gingival hypertrophy, horizontal nystagmus, and teratogenicity. Carbamazepine may be associated with bone marrow suppression. Tocainide was associated with bone marrow suppression and pulmonary fibrosis, and is no longer marketed in the United States. Mexiletine is often poorly tolerated due to gastrointestinal upset. Although studied tricyclic antidepressants have a comparatively high likelihood of efficacy, the magnitude of their efficacy may be somewhat limited, and their sedative and anticholinergic side effects can limit tolerability.

Newer drugs have been developed, or are in development, with better safety/tolerability profiles. Some of these have been launched as anticonvulsants, and are currently still in clinical trials for neuropathic pain. For example, oxcarbazepine, a carbamazepine derivative, is also a sodium channel blocker, and it was developed to retain the anticonvulsant efficacy of carbamazepine while avoiding the hepatic enzyme induction believed to be associated with an epoxide metabolite. ${ }^{37,38}$ Oxcarbazepine has given positive results in two controlled, painful diabetic neuropathy trials, as well as a number of open label studies. ${ }^{39,40}$ Similarly, lamotrigine, whose pharmacology includes NMDA receptor antagonism, as well as sodium channel blockade, has been efficacious in painful diabetic neuropathy, central poststroke pain, HIV-related painful neuropathy, and in spinal cord injury patients with incomplete (but not complete) transections. A tolerability consideration with lamotrigine therapy is the $8 \%$ to $9 \%$ incidence of rash. Lacosamide, another new anticonvulsant, has been proposed to bind to a novel site that enhances slow inactivation, thus increasing a physiological mechanism of channel inhibition. ${ }^{41}$ Lacosamide has shown positive results in painful diabetic peripheral neuropathy in phase II and III clinical trials. Successful registration of these agents for use in neuro- 


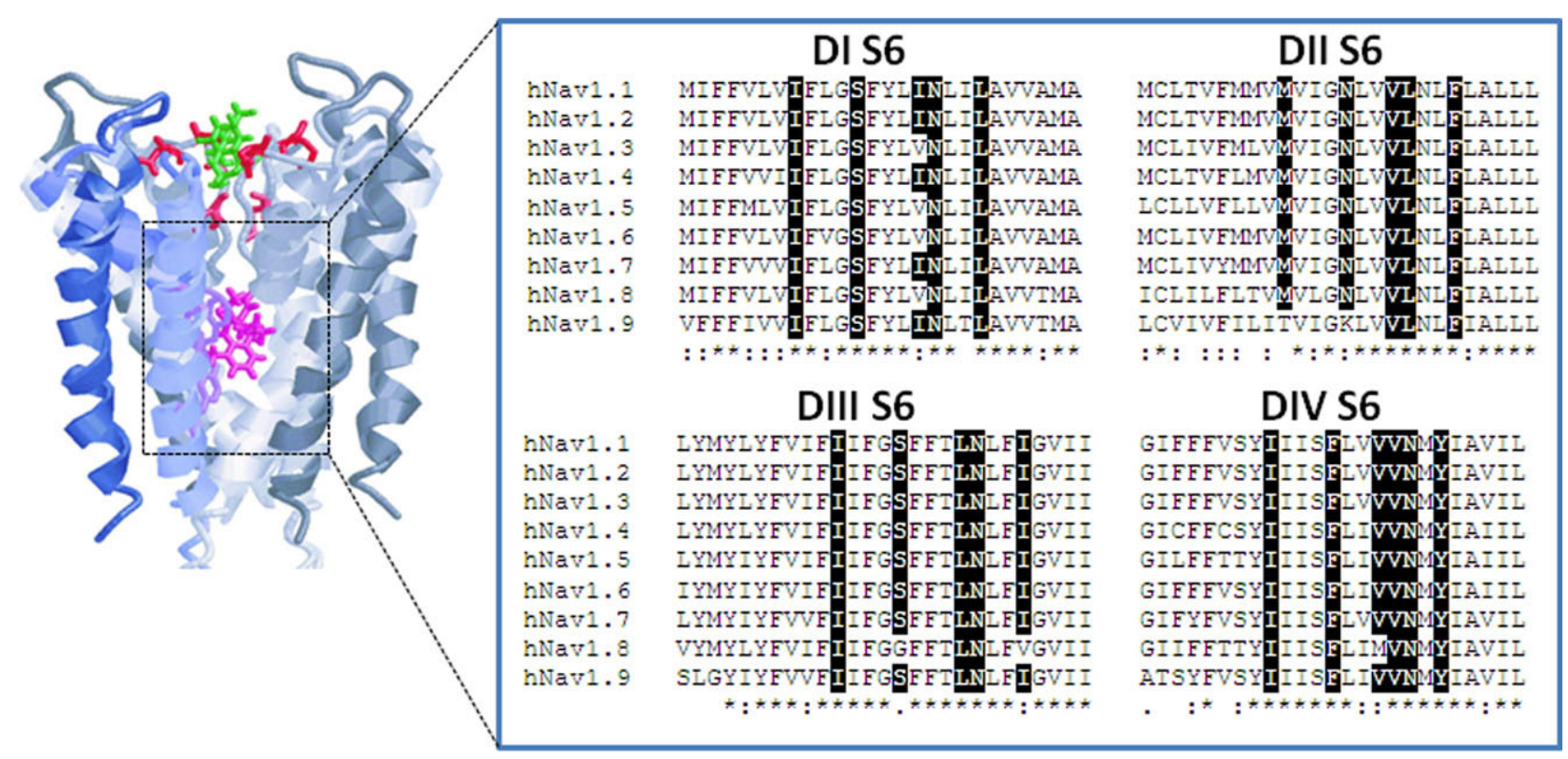

FIG. 1. Illustration of the local anesthetic binding site on the sodium channel $\alpha$ subunit, with inset showing high amino acid sequence homology among the nine sodium channel subtypes. Shaded areas indicate residues shown by either experimentation or modeling to interact with local anesthetic-like drugs. (Reprinted from Catterall WA, 2000, ${ }^{165}$ with permission from Elsevier, with modification.)

pathic pain will expand the armamentarium considerably.

Three agents in development specifically for pain indications are 4030W92, ralfinamide, and tetrodotoxin. 4030W92 did not demonstrate efficacy in neuropathic pain at a dose of $25 \mathrm{mg}{ }^{42}$ Positive results for ralfinamide (80-320 mg/day, as tolerated) in a phase II mixed etiology, neuropathic pain trial were presented in poster form in 2008 (see Table 1). Tetrodotoxin (TTX), the nonpeptide bacterial toxin concentrated in the internal organs of many species of ray-finned fish of the order Tetraodontiformes, is a commonly used laboratory reagent in the study of sodium channels, and it is both highly potent and exquisitely selective for sodium channels as a class. Most sodium channels are sensitive to block by tetrodotoxin, with the exception of the cardiac channel and some neuronal channels (see below). Tetrodotoxin is in clinical trials for the treatment of pain, and has been studied in patients with severe cancer pain, including patients with neuropathic pain. A recent trial did not yield statistically significant results for the primary outcome measure, but suggested possible efficacy based on individual responders and secondary outcome measures. Perioral tingling was common, and one patient experienced a severe but reversible adverse event of truncal and gait ataxia. ${ }^{43}$

Of note, with the sole exception of tetrodotoxin, all the agents previously described are distributed into the central nervous system as well as the peripheral compartment. However, the anatomical location of critical sodium channel blockade is difficult to localize. Studies have pointed to a spinal site of action of lidocaine, but this question is difficult to conclusively resolve. ${ }^{44}$ Effi- cacy of tetrodotoxin would provide evidence that blocking channels in peripheral nerves is adequate for effect; however, tolerability of tetrodotoxin seems to be limited by motor blockade.

\section{MECHANISM OF BLOCK}

A generalization regarding the above trials is that agents that are both efficacious and well tolerated are use-dependent sodium channel blockers. Compounds exhibiting strong use-dependent effects are often referred to as local anesthetic-like. A diverse group of drugs have local anesthetic-like properties, including anesthetics, anti-convulsants, anti-arrhythmics, and other various miscellaneous drugs. ${ }^{45-49}$ Local anesthetic-like drugs bind at a site composed of residues in the inner pore region of the sodium channel, a motif that is highly conserved across all mammalian voltage-gated sodium channels. As a result of recognizing this conserved motif, they do not exhibit subtype selectivity (FIG. 1). Usedependence (or frequency dependence) describes a phenomenon whereby compounds preferentially block sodium channels that are rapidly cycling between resting, open, and inactivated states of the channel (such as may occur in tissues firing action potentials at high frequency) compared to those that reside for prolonged periods in the closed state (such as may occur in tissues firing action potentials at low frequencies). ${ }^{50-52}$ At the molecular level, frequency/use-dependence is a reflection of the ability of drugs to bind in a state-dependent manner, binding with low affinity to closed channels and relatively high affinity to open and/or inactivated channels, 
according to the classical "modulated receptor hypothesis" $" 53$ (for review, see Hondeghem and Katzung ${ }^{54}$ ). Once bound to the open/inactivated state, these local anesthetic-like drugs stabilize the inactivated conformation, preventing reactivation of the channel. The degree of use dependence exhibited by any given drug is a function of the on-rate and off-rate for the interaction between the drug and the open/inactivated states of the channel. Interestingly, most of the agents previously described exhibit low sodium channel potency (micromolar, and in some cases high micromolar, in vitro potencies at sodium channels) with relatively fast off-rates, and strong usedependence. This strong use-dependence provides for a safety margin for efficacy without impairment of critical cardiac, neuromuscular, or ordinary sensory functions. Despite this, it is clear that not all patients benefit from these drugs, and these compounds often provoke doselimiting side effects. There is clearly a need for secondgeneration sodium channel blockers with improved efficacy and/or fewer side effects. Because all clinically used sodium channel blockers lack sodium channel subtype selectivity (i.e., they block all voltage-gated sodium channels with similar potency), a generally held view is that improvements in subtype selectivity are required for advances over currently available drugs. The following sections will discuss the rationale for subtype-selective sodium channel blockers in the search for optimally efficacious, safe, and tolerable therapeutics.

\section{VOLTAGE-GATED SODIUM CHANNELS}

Voltage-gated sodium channels function as heteromultimeric proteins that consist of the pore forming $\alpha$ subunit in association with an auxiliary $\beta$ ( $\beta 1-\beta 4)$ subunit. The $260 \mathrm{kDa}$ mammalian $\alpha$ subunit is encoded by nine distinct genes, giving rise to sodium channels $\mathrm{Na}_{\mathrm{v}} 1.1$ through $\mathrm{Na}_{\mathrm{v}} 1.9$ (for a complete description of nomenclature, see the 2003 International Union of Pharmacology Compendium of Voltage Gated Channels ${ }^{55}$ ), and is composed of four homologous domains, with each domain spanning the membrane six times (S1-S6) consistent with the architecture of the classical voltage-gated ion channel superfamily. ${ }^{56}$ The sodium channel $\alpha$ subunit determines the biophysical properties of the channel and contains the ion selectivity filter. Modification of the $\alpha$ subunit alters the properties of the channel, whether due to binding of exogenous ligands, such as small molecules or neurotoxins/peptides, modulation by endogenous intracellular signaling molecules, such as protein kinases $\mathrm{A}$ and $\mathrm{C}$, or amino acid sequence alteration due to genetic manipulation or naturally occurring polymorphisms. Sodium channels are commonly annotated as either tetrodotoxin sensitive $\left(\mathrm{Na}_{\mathrm{v}} 1.1-\mathrm{Na}_{\mathrm{v}} 1.4, \mathrm{Na}_{\mathrm{v}} 1.6\right.$, $\left.\mathrm{Na}_{\mathrm{v}} 1.7\right)$ or resistant $\left(\mathrm{Na}_{\mathrm{v}} 1.5, \mathrm{Na}_{\mathrm{v}} 1.8, \mathrm{Na}_{\mathrm{v}} 1.9\right)$. In addition to tetrodotoxin, a host of other peptide toxins isolated from scorpions, spiders, sea anemones, and cone snails modulate channel function, and to date, six different neurotoxin binding sites have been defined on the $\alpha$ subunit of the sodium channel (see FIG. 2). ${ }^{57,58}$

\section{SODIUM CHANNELS AND PAIN}

Eight of the nine sodium channel subtypes are expressed in the DRG; the exception is $\mathrm{Na}_{\mathrm{v}} 1.4$, whose expression is confined to the skeletal muscle. Three of these eight, $\mathrm{Na}_{\mathrm{v}} 1.7,1.8$, and 1.9, are expressed exclusively in the peripheral nervous system; $\mathrm{Na}_{\mathrm{v}} 1.3$ is ordinarily only expressed during embryonic development but is re-expressed by neurons after injury. Five subtypes are expressed in the brain: $\mathrm{Na}_{\mathrm{v}} 1.1-1.3, \mathrm{Na}_{\mathrm{v}} 1.5$, and $\mathrm{Na}_{\mathrm{v}} 1.6$. Of interest, a recent report found splice variant differences between brain and cardiac $\mathrm{Na}_{\mathrm{v}} 1.5$ in both rat and human, and suggested that the properties of the cardiac and brain versions of the channel may therefore differ. ${ }^{59}$

Most interest in selective sodium channel drug discovery centers on $\mathrm{Na}_{\mathrm{v}} 1.3, \mathrm{Na}_{\mathrm{v}} 1.7, \mathrm{Na}_{\mathrm{v}} 1.8$, and $\mathrm{Na}_{\mathrm{v}} 1.9$, and the evidence that these channels contribute to neuropathic pain will be briefly reviewed. Recent clinical descriptions of $\mathrm{Na}_{\mathrm{v}} 1.7$ gain and loss of function mutations in probands from affected families have brought a great deal of attention to the role of this channel in all forms of pain perception, as described in greater detail below.

Due to both anatomical distribution and to the substantial safety concerns inherent in targeting channels that are critical for normal brain or cardiac function, less attention has centered on the potential for selective blockade of $\mathrm{Na}_{\mathrm{v}} 1.1,1.2,1.4,1.5$, and 1.6 for the treatment of neuropathic pain. Both gain of function and loss of function mutations in $\mathrm{Na}_{\mathrm{v}} 1.1$ lead to epilepsy. ${ }^{60}$ One mutation has been associated with familial hemiplegic migraine. ${ }^{61}$ Various mutations that alter properties of $\mathrm{Na}_{\mathrm{v}} 1.2$ result in epilepsy syndromes as well. ${ }^{62-71} \mathrm{Na}_{\mathrm{v}} 1.4$ is required for normal skeletal muscle function. ${ }^{72-74}$ $\mathrm{Na}_{\mathrm{v}} 1.5$ is predominantly expressed on cardiac myocytes and is essential to cardiac action potential initiation and conduction. ${ }^{75}$ Pharmacological inhibition or genetic mutations of $\mathrm{Na}_{\mathrm{v}} 1.5$ interfere with channel function, resulting in disruption of cardiac excitability leading to arrhythmias. ${ }^{76,77}$ Humans and rodents with decreased function of $\mathrm{Na}_{\mathrm{v}} 1.6$, predominantly located at nodes of Ranvier, exhibit neuropsychological abnormalities and motor impairment rather than sensory deficits. ${ }^{78}$

\section{DISTRIBUTION AND FUNCTION OF "PAINFUL" SODIUM CHANNELS}

Studies of the anatomical distribution and regulation of sodium channel expression in experimental preclinical pain states have contributed somewhat to our current understanding of the role of the various subtypes in 


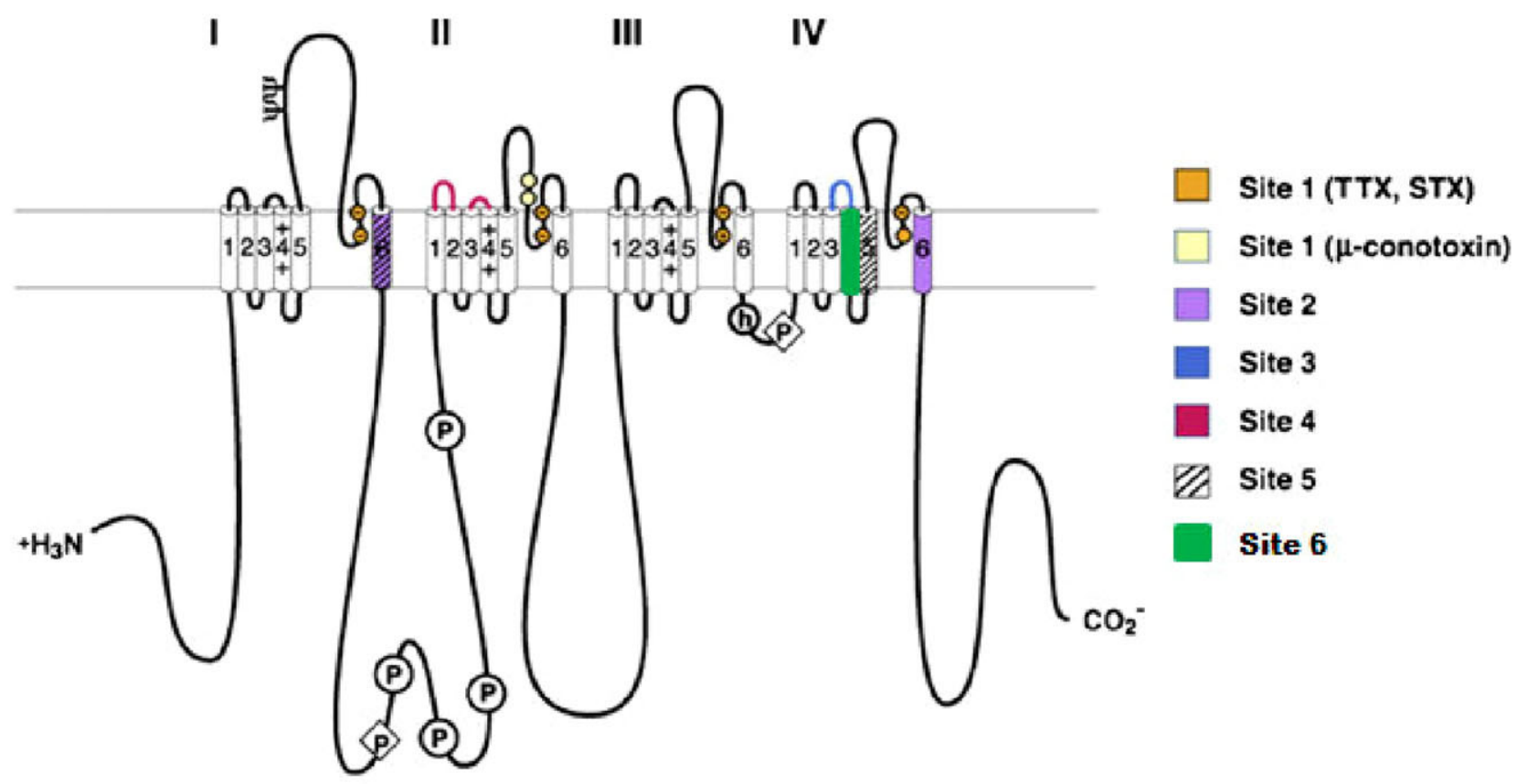

\begin{tabular}{|c|c|c|c|}
\hline $\begin{array}{l}\text { Binding } \\
\text { site }\end{array}$ & Neurotoxin & Effect & Small molecule \\
\hline Site 1 & $\begin{array}{l}\text { Tetrodotoxin } \\
\text { Saxitoxin } \\
\mu \text {-Conotoxin }\end{array}$ & $\begin{array}{l}\text { Pore block } \\
\text { Pore block } \\
\text { Pore block }\end{array}$ & Not known \\
\hline Site 2 & $\begin{array}{l}\text { Batrachotoxin } \\
\text { Grayanotoxin }\end{array}$ & $\begin{array}{l}\text { Pore block } \\
\text { Activation gate } \\
\text { modulation }\end{array}$ & $\begin{array}{l}\text { Local anesthetics } \\
\text { Antiarrhythmics } \\
\text { Tricyclic } \\
\text { antidepressants } \\
\text { Veratridine }\end{array}$ \\
\hline Site 3 & $\begin{array}{l}\alpha \text {-Scorpion } \\
\text { toxins } \\
\text { Sea anemone } \\
\text { toxins }\end{array}$ & $\begin{array}{l}\text { Slow inactivation } \\
\text { Slow inactivation }\end{array}$ & Not known \\
\hline Site 4 & $\begin{array}{l}\beta \text {-Scorpion } \\
\text { toxins } \\
\text { Protoxin-I/II }\end{array}$ & $\begin{array}{l}\text { Activation gate } \\
\text { modulation } \\
\text { Activation gate } \\
\text { modulation }\end{array}$ & Not known \\
\hline Site 5 & Brevetoxin & Enhanced activation & Not known \\
\hline Site 6 & $\delta$-Conotoxins & $\begin{array}{l}\text { Inactivation gate } \\
\text { modulation }\end{array}$ & Not known \\
\hline
\end{tabular}

FIG. 2. Diagram of toxin binding sites on the sodium channel $\alpha$ subunit. Table 1 lists toxins known to bind at identified sites (color-coded on diagram) and corresponding effects on channel function. (STX = saxitoxin; TTX = tetrodotoxin.) (Reprinted from Catterall WA, et al., 2007, ${ }^{57}$ with permission from Elsevier, with modification.) 
pathophysiology. In a few cases, human tissue samples from patients with clinically described pain states have been available as well. Techniques enabling selective manipulation of the expression of specific subtypes, using knockout or mRNA knockdown, have been used to study the relative contribution of different gene products as well. It is difficult to make robust interpretations of these data, because distribution evidence is descriptive and circumstantial rather than dispositive, and genetic studies in mice have been somewhat inconclusive. In the case of $\mathrm{Na}_{\mathrm{v}} 1.7$, genetic studies in mice have been in less than complete agreement with human evidence. Nevertheless, these important studies continue to teach us about human pain mechanisms, reveal to us what there is still to learn, and document potential species differences that delineate gaps between rodent and human pathophysiology.

\section{$\mathrm{Na}_{\mathrm{v}} 1.3$}

$\mathrm{Na}_{\mathrm{v}} 1.3$ expression is developmentally regulated, with widespread expression observed in the developing nervous system and lower levels of expression in the adult. There appears to be significant differences between the adult levels of expression in the rat compared to the human; however, although $\mathrm{Na}_{\mathrm{v}} 1.3$ is expressed only in restricted areas of the rat brain, messenger RNA is readily detected in almost all areas of the human brain. ${ }^{79}$ Of note, upregulation of $\mathrm{Na}_{\mathrm{v}} 1.3$ may be a response to neuronal injury, as increases in expression in primary sensory neurons have been repeatedly described after nerve transection and inflammation. ${ }^{80-83}$ In the naïve rat DRG, only $6.3 \%$ of neurons expressed $\mathrm{Na}_{\mathrm{v}} 1.3$; after L5 axotomy, expression was seen in $40 \%$ of DRG neurons, in cells of all sizes, but predominantly in medium- and large-diameter neurons. ${ }^{84}$ Upregulation in secondary neurons in the ventroposterolateral nucleus of the thalamus has been demonstrated after peripheral nerve injury as well. ${ }^{85}$ Seizure activity also appears to induce increases in hippocampal channel expression, as described in rat models of spontaneous and kainate-induced epilepsy. ${ }^{86,87}$ The upregulation of $\mathrm{Na}_{\mathrm{v}} 1.3$ channels, along with their fast recovery from inactivation is speculated to contribute a critical role in the hyperexcitability of damaged neurons. Curiously, the role of $\mathrm{Na}_{\mathrm{v}} 1.3$ in initiation and maintenance of neuropathic pain is not supported by knockout studies, because constitutive null mutants develop similar neuropathic pain behavior and ectopic neuronal discharge to wild type controls. ${ }^{88}$ Studies using antisense knockdown of $\mathrm{Na}_{\mathrm{v}} 1.3$ have provided conflicting results, with knockdown after spinal cord injury reducing neuropathic signs, but knockdown after peripheral nerve injury producing no reduction in pain behaviors. ${ }^{85,89,90}$

\section{$\mathrm{Na}_{\mathbf{v}} \mathbf{1 . 7}$}

$\mathrm{Na}_{\mathrm{v}} 1.7$ expression is restricted predominantly to the peripheral nervous system. It is abundantly expressed in the DRG, sympathetic ganglia, and in peripheral terminals of both high- and low-threshold sensory neurons. ${ }^{91,92}$ In the naïve $\mathrm{DRG}, \mathrm{Na}_{\mathrm{v}} 1.7$ is expressed by most neurons $(83 \%-86.8 \%)$ across all size profiles. In a variant of the chronic constriction injury of the rat sciatic nerve, Nav1.7 mRNA expression was significantly decreased $(54.1 \%)$ in the ipsilateral L4 and L5 DRG, but unchanged in the proximal sciatic nerve segment. ${ }^{93}$ However, accumulation of $\mathrm{Na}_{\mathrm{v}} 1.7$ has been described in human painful neuromata. ${ }^{94} \mathrm{Na}_{\mathrm{v}} 1.7$ channels recover slowly from inactivation and display slow inactivation at voltages around the resting membrane potential, thereby contributing to the threshold setpoint for action potential generation. ${ }^{95} \mathrm{Na}_{\mathrm{v}} 1.7$ global knockout mouse pups die shortly after birth, possibly due to anosmia leading to impaired feeding. This lethality was circumvented by engineering a "nociceptor-specific" knockout line in which null expression of $\mathrm{Na}_{\mathrm{v}} 1.7$ was governed by the $\mathrm{Na}_{\mathrm{v}} 1.8$ promoter. $^{96}$ The resulting mice displayed a marked deficit in noxious thermal and mechanical sensitivity, and loss of inflammatory thermal and mechanical hyperalgesia. Nevertheless, they developed mechanical allodynia after nerve injury that was indistinguishable from wild-type mice. ${ }^{97}$ Although the authors interpreted these findings to mean that $\mathrm{Na}_{\mathrm{v}} 1.7$ appears not be involved in the development of neuropathic pain, a more cautious interpretation is that $\mathrm{Na}_{\mathrm{v}} 1.7$ expression in neuronal subclasses expressing $\mathrm{Na}_{\mathrm{v}} 1.8$ is not required for the development of neuropathic pain. Because $\mathrm{Na}_{\mathrm{v}} 1.8$ is not expressed in the majority of $\mathrm{A} \beta$ neurons, and because $\mathrm{A} \beta$ neurons are strongly implicated in the development of neuropathic pain and allodynia, the pattern of $\mathrm{Na}_{\mathrm{v}} 1.7$ knockout may have been too restricted in these constructs to fully assess its role. ${ }^{98,99}$ Of note, in this instance, the interpretation of mouse data has been upstaged by findings from human genetic studies. Two heritable pain disorders have been associated with mutations in the $\mathrm{Na}_{\mathrm{v}} 1.7$ gene (SCN9A). Patients carrying one class of gain of function mutations in the SCN9A gene suffer from a pain syndrome known as paroxysmal extreme pain disorder, whereas those with another class of gain of functions suffer from a pain syndrome known as erythromelalgia or erythermalgia. ${ }^{100,101}$ Congenital indifference to pain, which is linked to truncation of the SCN9A gene resulting in loss of channel function, is an even more striking clinical phenotype. ${ }^{102-105}$ Although these subjects lack the ability to sense any form of pain, they retain otherwise normal mechanical and thermosensory function and normal autonomic physiology. Recent reports have pointed to anosmia as a possible additional feature of this phenotype. ${ }^{104}$ Some of these mutations have been studied at the molecular level in vitro for their effects on gating proper- 
ties. $^{106}$ The erythromelalgia mutations (I136V, F216S, S241T, N395K, I848T, L858H, L858F, A863P, F1449V) shift the activation curve to hyperpolarized voltages, lowering the activation threshold and resulting in hyperexcitability. ${ }^{107-114}$ In contrast, the paroxysmal extreme pain disorder mutations (R996C, V1298F, V1298D, V1299F, I1461T, F1462V, T1464I, M1627K) shift the steady state inactivation to more depolarized potentials, resulting in greater channel availability. ${ }^{100,115,116}$

\section{$\mathrm{Na}_{\mathbf{v}} 1.8$}

$\mathrm{Na}_{\mathrm{v}} 1.8$ channels are exclusively restricted to the periphery. The steady state inactivation of $\mathrm{Na}_{\mathrm{v}} 1.8$ is relatively (compared with other sodium channels) right shifted, and consequently more channels are available for activation at physiological voltages. These channels may contribute to the longer action potential durations and action potential overshoots associated with nociceptive neurons, and the presence of $\mathrm{Na}_{\mathrm{v}} 1.8$ is thus associated with a nociceptive role. ${ }^{98}$ Unlike TTX-sensitive channels, the inactivation properties of $\mathrm{Na}_{\mathrm{v}} 1.8$ are entirely cold-resistant, and as a result, $\mathrm{Na}_{\mathrm{v}} 1.8$ is essential to the perception of cold pain. ${ }^{17,118}$ In naïve DRGs, $\mathrm{Na}_{\mathrm{v}} 1.8$ is expressed in $66.5 \%$ to $68.9 \%$ of neurons overall, mostly those with small- and medium-sized profiles. After axotomy, expression in the affected DRG decreases dramatically, although redistribution to the axonal injury site has been reported. ${ }^{93,119-121}$ Although $\mathrm{Na}_{\mathrm{v}} 1.8$ enjoys a comparatively undisputed role in inflammatory pain states, its role in neuropathic pain has been somewhat controversial, with temporal knockdown studies indicating a critical component of $\mathrm{Na}_{\mathrm{v}} 1.8$ in neuropathic pain, electrophysiological studies showing a lack of ectopic neuronal discharges in nerve injured null mutant mice compared to the wild type, but normal development of neuropathic pain in constitutive knockout mice. ${ }^{97,118,122-125}$

\section{$\mathrm{Na}_{\mathbf{v}} 1.9$}

$\mathrm{Na}_{\mathrm{v}} 1.9$ is still the least understood member of the sodium channel family, mostly because of the difficulty in expressing the protein in recombinant systems. This subtype is expressed in the sensory ganglia, mainly in small diameter C fibers (58.8\%-61.5\% of DRG neurons overall). ${ }^{84,126,127}$ The $\mathrm{Na}_{\mathrm{v}} 1.9$ subtype is unique among sodium channels in that it displays slow activation and incomplete inactivation. ${ }^{128}$ This channel was upregulated in innervating DRGs after hind paw inflammation, and was downregulated after axotomy. ${ }^{129,130}$ Using knockdown technology with antisense oligonucleotides, it was demonstrated that $\mathrm{Na}_{\mathrm{v}} 1.9$ may not be involved in acute nociception or in producing thermal hyperalgesia or mechanical allodynia in spinal nerve ligated rats. ${ }^{131}$ Likewise, acute pain responses were unaltered in $\mathrm{Na}_{\mathrm{v}} 1.9$ knockout animals and neuropathic pain behavior was observed for the entire duration of the study. ${ }^{132}$ In sharp contrast, $\mathrm{Na}_{\mathrm{v}} 1.9$ in knockout mice failed to maintain inflammation-induced thermal hyperalgesia with no effect on the mechanical endpoint, suggesting that $\mathrm{Na}_{\mathrm{v}} 1.9$ may be important for aspects of persistent inflammatory pain. ${ }^{133}$

\section{THE SEARCH FOR SUBTYPE SELECTIVE SODIUM CHANNEL BLOCKERS}

As previously noted, there exists a clear need for new sodium channel blockers with improved efficacy and/or fewer side effects. A popular view is that this could be achieved through improvements in subtype selectivity. Consequently, a great deal of effort has been expended in the pharmaceutical industry toward identifying selective inhibitors of one or more of the molecular sodium channel targets previously described. Unfortunately, progress in this endeavor has been slow. The vast majority of compounds identified to date, although often chemically novel (i.e., not related to first generation sodium channel blockers), do not appear to show improved subtype selectivity in comparison with existing drugs. Based on publicly disclosed information available at the time of writing, it would seem unlikely that any genuinely subtype selective sodium channel blockers are advancing through clinical trials. Only a few examples of subtype selective sodium channel blockers can be found in the scientific literature or in company press releases, and these examples are reviewed briefly below. Although these recent breakthroughs may provide evidence that subtype selectivity is indeed possible, it is clear that current screening paradigms are inefficient and novel approaches are needed. Some thoughts on future directions for sodium channel drug discovery are provided at the end of this section.

\section{A-803467: a subtype selective blocker of $\mathrm{Na}_{\mathrm{v}} 1.8$}

The first genuinely subtype selective small molecule sodium channel blocker to be described in the scientific literature was A-803497 ([5-(4-chlorophenyl-N-(3,5-dimethoxyphenyl)furan-2-carboxamide]). ${ }^{134}$ A-803497 was discovered by a team of Abbott and Icagen scientists with an iterative screening strategy, using a $\mathrm{Na}_{\mathrm{v}} 1.8$ isotopic flux assay, and whole cell voltage clamp to establish structure activity relationships for both potency and selectivity of $\mathrm{Na}_{\mathrm{v}} 1.8$ block. ${ }^{134,135}$ A-803497 blocks $\mathrm{hNa}_{\mathrm{v}} 1.8$ in a moderately state-dependent manner, with an $\mathrm{IC}_{50}$ for block of the channel in the resting state $\left(\mathrm{IC}_{50 \text { rest }}\right)$ of $79 \mathrm{nM}$, and an $\mathrm{IC}_{50}$ for block in the inactivated state $\left(\mathrm{IC}_{50}\right.$ inact $)$ of $8 \mathrm{nM}$. Block also appeared dependent on species and cellular context, with lower potency against rat $\mathrm{Na}_{\mathrm{v}} 1.8\left(\mathrm{IC}_{50}\right.$ inact $\left.=45 \mathrm{nM}\right)$ and native TTX-resistant sodium current in rat DRG neurons $\left(\mathrm{IC}_{50}\right.$ inact $=140$ $\mathrm{nM})$. Interestingly, unlike most small molecule sodium channel blockers, inhibition of $\mathrm{hNa}_{\mathrm{v}} 1.8$ by A-803497 was not frequency dependent, possibly indicating a dif- 
ferent mode of interaction compared with classical local anesthetic-like sodium channel blockers. ${ }^{134}$ In contrast to the impressive potency measured against $\mathrm{hNa}_{\mathrm{v}} 1.8$, A-803497 appeared considerably less potent against other closely related voltage-gated sodium channels. Under comparable recording conditions (holding potential $=$ $\mathrm{V} 1 \frac{1}{2}$ inact), the $\mathrm{Na}_{\mathrm{v}} 1 . \mathrm{x}: \mathrm{Na}_{\mathrm{v}} 1.8$ selectivity ratios were 923, 306, 918, and 843 for $\mathrm{hNa}_{\mathrm{v}} 1.2, \mathrm{hNa}_{\mathrm{v}} 1.3, \mathrm{hNa}_{\mathrm{v}} 1.5$, and $\mathrm{hNa}_{\mathrm{v}} 1.7$, respectively. In vivo, A-803497 significantly reduced spontaneous and evoked firing of spinal dorsal horn neurons in spinal nerve ligated rats. ${ }^{136}$ In behavioral pain models, A-803497 attenuated mechanical allodynia in the L5/L6 spinal nerve ligation and chronic constriction injury models of neuropathic pain, reduced thermal hyperalgesia in the complete Freund's adjuvant (CFA) model of inflammatory pain and suppressed acute mechanical nociception. Cold allodynia was also reduced in the chronic constriction injury model. Free plasma concentrations at efficacious doses in the spinal nerve ligation model were in close agreement with in vitro estimates of potency against TTX-resistant currents in rat DRG. Given the high degree of selectivity of this compound, these data strongly support a role for $\mathrm{Na}_{\mathrm{v}} 1.8$ in a variety of pain states. Furthermore, the finding that A-803497 did not significantly alter motor coordination at and above efficacious doses may provide the first direct experimental evidence to suggest that improvements in subtype selectivity will translate into improved safety/tolerability of sodium channel blockers.

\section{Subtype selective sodium channel modulators from Vertex}

In December 2005, GlaxoSmithKline and Vertex Pharmaceuticals announced that they had entered into an agreement to develop and commercialize VX-409, a novel, subtype selective sodium channel modulator for the treatment of pain (http://investors.vrtx.com/releasedetail. cfm?ReleaseID=233027). VX-409 was described as an orally bioavailable, highly active compound with a good safety profile in nonclinical models of both neuropathic and inflammatory pain. However, details of the structure of the compound or the target sodium channel were not disclosed. Phase I clinical development of VX-409 was expected to be initiated early in 2007. However, by 2007 , GlaxoSmithKline had discontinued the preclinical development of VX-409 for the treatment of pain, although the reasons for discontinuation were not disclosed, and the agreement between the two companies was terminated by April 2008.

\section{Novel $\mathrm{Na}_{\mathbf{v}} \mathbf{1 . 7}$ blockers from Merck}

Using a fluorescence resonance energy transfer (FRET) assay, scientists at Merck identified a series of benzazepinone sodium channel blockers. ${ }^{137-140}$ Compounds from this family potently inhibited veratridine-induced depolarization in HEK293 cells stably expressing
$\mathrm{hNa}_{\mathrm{v}} 1.7$ channels. Interestingly, some members of this family displayed modest selectivity for $\mathrm{Na}_{\mathrm{v}} 1.7$ in comparison with $\mathrm{Na}_{\mathrm{v}} 1.8$ and the cardiac $\mathrm{Na}_{\mathrm{v}} 1.5$ channel. For example, Compound $4^{140}$ (also known as Compound $32^{139}$ ) inhibited the $\mathrm{Na}_{\mathrm{v}} 1.7$ FRET signal with an $\mathrm{IC}_{50}$ value of $0.03 \mu \mathrm{M}$. In similar FRET-based assays, however, Compound 4 appeared less potent at blocking $\mathrm{Na}_{\mathrm{v}} 1.8\left(\mathrm{IC}_{50}\right.$ of $0.3 \mu \mathrm{M}$ [i.e., $10 \times$ selective] $)$ and $\mathrm{Na}_{\mathrm{v}} 1.5$ ( $\mathrm{IC}_{50}$ of $0.18 \mu \mathrm{M}$ [i.e., $6 \times$ selective]). Other compounds, such as Compound 7 and Compound 9, although less potent against $\mathrm{Na}_{\mathrm{v}} 1.7$, appeared slightly more selective. The interaction of Compound 4 with $\mathrm{Na}_{\mathrm{v}} 1.7, \mathrm{Na}_{\mathrm{v}} 1.8$, and $\mathrm{Na}_{\mathrm{v}} 1.5$ channels was further characterized in whole cell electrophysiology. Minimal block was observed when compound 4 was applied to $\mathrm{hNa}_{\mathrm{v}} 1.7$ channels at -100 $\mathrm{mV}$. In contrast, the $\mathrm{IC}_{50}$ for block of $\mathrm{Na}_{\mathrm{v}} 1.7$ at $-65 \mathrm{mV}$ was $0.55 \mu \mathrm{M}$, suggesting that compound 4 interacts selectively with channels in the inactivated state. Compound 4 was less potent at inhibiting $\mathrm{hNa}_{\mathrm{v}} 1.5$ and $\mathrm{hNa}_{\mathrm{v}} 1.8$ channels; $\mathrm{IC}_{50}$ values for block of inactivated $\mathrm{hNa}_{\mathrm{v}} 1.5$ and $\mathrm{hNa}_{\mathrm{v}} 1.8$ were $4.3 \mu \mathrm{M}$ and $5.5 \mu \mathrm{M}$, respectively. These findings were in close agreement with observations from the fluorescent assays and suggested that Compound 4 is a potent, state-dependent $\mathrm{Na}_{\mathrm{v}} 1.7$ blocker that exhibits approximately 10 -fold selectivity for $\mathrm{Na}_{\mathrm{v}} 1.7$ in comparison with $\mathrm{Na}_{\mathrm{v}} 1.5$ and $\mathrm{Na}_{\mathrm{v}} 1.8$. Consistent with an important role for $\mathrm{Na}_{\mathrm{v}} 1.7$ in pain transmission/sensation, Compound 4 (also known as Compound 32) proved to be highly efficacious in a rat spinal nerve ligation model of neuropathic pain. When dosed orally at 10 $\mathrm{mg} / \mathrm{kg}$, Compound 32 elicited significant reversal of allodynia at $2 \mathrm{~h}$ postdose (\% reversal). ${ }^{139}$ In 2008, Merck scientists described a related series of imidazopyridines. ${ }^{141}$ As for the parent benzazepinone series, several members of the imidazopyridine family exhibited modest selectivity for $\mathrm{Na}_{\mathrm{v}} 1.7$ in comparison with $\mathrm{Na}_{\mathrm{v}} 1.8$ (up to $7 \times$ [e.g., Compound 43]). The selectivity of these compounds for $\mathrm{Na}_{\mathrm{v}} 1.7$ in comparison with other sodium channel subtypes has not been reported.

\section{FUTURE DIRECTIONS}

As can be seen from the preceding section, very few examples of subtype selective sodium channel blockers exist in the scientific literature. Although there has been some progress, it is clear that current screening paradigms are less than adequate. Although the exact reason(s) are not clear, it seems highly likely that much of this inadequacy stems from limitations of currently available assays. Cell based, functional, fluorescence, or ion flux-based assays are typically the assays of choice for high throughput sodium channel screening. ${ }^{137,142-145}$ Although well suited to the screening of large compound collections, these assays have a number of significant limitations that may ultimately impact the probability of 
identifying subtype selective sodium channel blockers. For example, although accurate for the most part, assays reliant on membrane potential dyes are prone to artifacts. Fluorescent compounds, compounds that quench the fluorescence of the reporter dye, compounds causing precipitation of the dye, toxic compounds, ionophores, and membrane permeabilizing agents will all result in erroneous activity in fluorescent assays. Time wasted following erroneous hits will ultimately reduce the chances of success. However, these limitations are not unique to sodium channel screening and are unlikely to be the major reason for the industry-wide inability to identify subtype selective sodium channel blockers. A more likely explanation is that the assays commonly used for sodium channel screening are inherently biased toward detection of nonselective "local anesthetic-like" compounds.

The observation that currently available assays are inherently biased toward detection of local anesthetics is not at all surprising. The resting membrane potential of sodium channel-expressing cell lines is typically around $-40 \mathrm{mV}$, which favors sodium channel inactivation and local anesthetic binding. Numerous studies have demonstrated the high sensitivity of commonly used cell-based functional assays to local anesthetics and related compounds. ${ }^{137,142-144}$ However, few studies have rigorously explored the sensitivity of commonly used assays for mechanistically novel sodium channel modulators, such as the gating modifier spider toxins protoxin I and protoxin II, for example (see below). Although activity of protoxin I and protoxin II has been demonstrated in a voltage ion-probe reader (VIPR) FRET-based assay, the potency of these peptides appeared highly dependent on the duration of the assay. ${ }^{146,147}$ It is therefore possible that, unless suitably optimized, high throughput fluorescent assays may not be able to reliably detect compounds with protoxin II-like activity. Of course, even if all commonly used high throughput sodium channel assays were capable of detecting compounds with novel mechanisms, the difficult task remains of separating the mechanistically novel compounds from the nonselective local anesthetic-like compounds. Given the high sensitivity of these assays for local anesthetic compounds, it seems that in all likelihood, nonselective local anesthetic-like compounds will far outnumber the potentially more interesting novel compounds. Finding the "needles" in this "haystack" of nonselective compounds will remain a major challenge.

In our opinion, the search for subtype selective sodium channel blockers would be greatly facilitated by the development of novel assays compatible with high throughput screening (HTS), with clearly demonstrated ability to detect mechanistically novel agents, and preferably with the ability to discriminate between mechanistically novel compounds and local anesthetics. Al- though electrophysiological assays could be configured to identify compounds acting via any conceivable mechanism, even the highest throughput electrophysiology assays (e.g., Ionworks Quattro) are not truly HTS compatible. ${ }^{148}$ A major stumbling block for development of novel assays to date has been a lack of suitable tools for assay validation. However, the spider toxins, protoxin I, protoxin II, and huwentoxin 4 , have recently been identified as mechanistically novel $\mathrm{Na}_{\mathrm{v}} 1.7$ blockers, and these peptides may therefore represent useful tools for development and validation of new assays. ${ }^{147,149-151}$ These peptides inhibit sodium channel function by shifting the voltage-dependence of gating to more depolarized potentials (i.e., they are gating modifiers, not pore blockers, and they are mechanistically very different from local anesthetics). These spider toxins bind at a site close to the voltage sensor, in a region of the channel that is distinct from the local anesthetic binding site, which exhibits a relatively low level of conservation across the various sodium channel subtypes. ${ }^{151-153}$ This lack of conservation is reflected in the unique selectivity profile of protoxin II. According to recent publications, protoxin II is between 10-fold and greater than 100-fold selective for $\mathrm{Na}_{\mathrm{v}} 1.7$ in comparison with all other voltage dependent subtypes. ${ }^{149,154}$ Thus, compounds binding at sites defined by gating modifier toxins such as protoxin II offer the potential for a degree of subtype selectivity far beyond that seen to date with local anesthetic-like compounds. Recently, scientists from Merck have described an ${ }^{125}$ I-protoxin II binding assay. ${ }^{149}$ In this assay, ${ }^{125}$ I-protoxin II bound with high affinity to $\mathrm{hNa}_{\mathrm{v}} 1.7$ and binding could be displaced with unlabelled protoxin I and protoxin II, with affinities of 680 and $389 \mathrm{pM}$, respectively. Interestingly, protoxin binding could not be displaced with tetrodotoxin, veratridine, $\alpha$-scorpion toxins (LqhaIT, Ltx-004), the sea anemone toxin anthopleurin $\mathrm{B}, \beta$-scorpion toxins (CssII, CssIV), brevetoxin, deltamethrin, or the local anesthetics tetracaine or mexiletine. ${ }^{146,149}$ Furthermore, protoxin II binding could not be demonstrated on cells expressing $\mathrm{Na}_{\mathrm{v}} 1.5$. Thus, this assay is sensitive to protoxins and insensitive to local anestheticlike agents. These findings suggest that the protoxin II binding assay may be well suited for identification of mechanistically novel, subtype selective sodium channel blockers. However, whether it will be possible to identify small molecules that bind to the protoxin II site and modify channel function in a subtype selective manner remains to be determined.

\section{CONCLUSIONS}

Sodium channel blockers have proven useful in the treatment of neuropathic pain. However, the use of currently available drugs is often limited by incomplete 
efficacy or poor tolerability. Due to the omnipresent role of sodium channels in vital physiological functions in addition to nociception, some form of selectivity of blockade is a safety requirement. To the extent that currently marketed sodium channel blockers are selective, it is on the basis of use- dependent inhibition of rapidly cycling channels. The degree of selectivity attainable with this strategy is limited because the channel motif targeted is common to all subtypes. An alternative approach, using different screening strategies to identify molecules that bind to distinctive channel subtype sequences in regions of structural divergence, is promising. Complicating this strategy, however, controversy exists regarding which channel subtypes are critical in the maintenance of neuropathic pain. This topic is of great ongoing interest in the field, and the reader is referred to additional recent reviews for further reading. ${ }^{155-164}$

\section{REFERENCES}

1. Mitchell SW. Gunshot Wounds and Other Injuries of Nerves. Philadelphia: Lippincott, 1864.

2. Rivera MA, Aufderheide AC, Cartmell LW, Torres CM, Langsjoen $\mathrm{O}$. Antiquity of coca-leaf chewing in the south central Andes: a 3,000 year archaeological record of coca-leaf chewing from northern Chile. J Psychoactive Drugs 2005;37:455-458.

3. Fairley HB. [Anesthesia in the Inca empire]. Rev Esp Anestesiol Reanim 2007;54:556-562.

4. Gaedcke F. Ueber das Erythroxylin, dargestellt aus den Blattern des in Sudamerika cultivirten Strauches Erythroxylon Coca Lam. Archiv der Pharmazie 1855;132:141-150.

5. Ruetsch YA, Boni T, Borgeat A. From cocaine to ropivacaine: the history of local anesthetic drugs. Curr Top Med Chem 2001;1: 175-182.

6. Jones AE. Sigmund Freud: Life and Work. London: Hogarth Press, 1953.

7. Cocaine Chemistry and New Local Anesthetics. Cal West Med 1926;25:232-233.

8. Taylor IB, Marks BW, Edmonds G. Intravenous administration of procaine hydrochloride during general anesthesia. Arch Surg 1949;59:714-723.

9. Phillips OC, Lyons WB, Harris LC, Nelson AT, Graff TD, Frazier TM. Intravenous lidocaine as an adjunct to general anesthesia: a clinical evaluation. Anesth Analg 1960;39:317-322.

10. Bigelow N, Harrison I. General analgesic effects of procaine. J Pharmacol Exp Ther 1944;81:368-373.

11. Lemoyne J. [Use of dimethyl-dithio-hydantoin in treatment of certain facial neuralgias.]. Ann Otolaryngol 1950;67:626-628.

12. Kugelberg E, Lindblom U. The mechanism of the pain in trigeminal neuralgia. J Neurol Neurosurg Psychiatry 1959;22:36-43.

13. Blom S. Trigeminal neuralgia: its treatment with a new anticonvulsant drug (G-32883). Lancet 1962;1:839-840.

14. Vaughan Williams EM. Classification of antidysrhythmic drugs. Pharmacol Ther [B] 1975;1:115-138.

15. Desanctis RW. Electrical Conversion of Ventricular Tachycardia. Jama 1965;191:632-636.

16. Carden NL, Steinhaus JE. Lidocaine in cardiac resuscitation from ventricular fibrillation. Circ Res 1956;4:680-683.

17. Vaughan Williams EM. A classification of antiarrhythmic actions reassessed after a decade of new drugs. J Clin Pharmacol 1984; 24:129-147.

18. Loeser JD, Ward AA, Jr., White LE, Jr.Chronic deafferentation of human spinal cord neurons. J Neurosurg 1968;29:48-50.

19. Burchiel KJ, Wyler AR. Ectopic action potential generation in peripheral trigeminal axons. Exp Neurol 1978;62:269-281.

20. Boas RA, Covino BG, Shahnarian A. Analgesic responses to i.v. lignocaine. Br J Anaesth 1982;54:501-505.
21. Petersen P, Kastrup J. Dercum's disease (adiposis dolorosa). Treatment of the severe pain with intravenous lidocaine. Pain 1987;28:77-80.

22. Kastrup J, Petersen P, Dejgard A, Angelo HR, Hilsted J. Intravenous lidocaine infusion-a new treatment of chronic painful diabetic neuropathy? Pain 1987;28:69-75.

23. Lindstrom $P$, Lindblom $U$. The analgesic effect of tocainide in trigeminal neuralgia. Pain 1987;28:45-50.

24. Dejgard A, Petersen P, Kastrup J. Mexiletine for treatment of chronic painful diabetic neuropathy. Lancet 1988;1:9-11.

25. Watson CP, Evans RJ, Reed K, Merskey H, Goldsmith L, Warsh J. Amitriptyline versus placebo in postherpetic neuralgia. Neurology 1982;32:671-673.

26. Leijon G, Boivie J. Central post-stroke pain-a controlled trial of amitriptyline and carbamazepine. Pain 1989;36:27-36.

27. Watson CP, Vernich L, Chipman M, Reed K. Nortriptyline versus amitriptyline in postherpetic neuralgia: a randomized trial. Neurology 1998;51:1166-1171.

28. Pancrazio JJ, Kamatchi GL, Roscoe AK, Lynch C, 3rd. Inhibition of neuronal $\mathrm{Na}+$ channels by antidepressant drugs. J Pharmacol Exp Ther 1998;284:208-214.

29. Barber MJ, Starmer CF, Grant AO. Blockade of cardiac sodium channels by amitriptyline and diphenylhydantoin. Evidence for two use-dependent binding sites. Circ Res 1991;69:677-696.

30. Dick IE, Brochu RM, Purohit Y, Kaczorowski GJ, Martin WJ, Priest BT. Sodium channel blockade may contribute to the analgesic efficacy of antidepressants. J Pain 2007;8:315-324.

31. Govrin-Lippmann R, Devor M. Ongoing activity in severed nerves: source and variation with time. Brain Res 1978;159:406410 .

32. Bennett GJ, Xie YK. A peripheral mononeuropathy in rat that produces disorders of pain sensation like those seen in man. Pain 1988;33:87-107.

33. Seltzer Z, Dubner R, Shir Y. A novel behavioral model of neuropathic pain disorders produced in rats by partial sciatic nerve injury. Pain 1990;43:205-218.

34. Kim SH, Chung JM. An experimental model for peripheral neuropathy produced by segmental spinal nerve ligation in the rat. Pain 1992;50:355-363.

35. Kajander KC, Wakisaka S, Bennett GJ. Spontaneous discharge originates in the dorsal root ganglion at the onset of a painful peripheral neuropathy in the rat. Neurosci Lett 1992;138: 225-228.

36. Devor M, Wall PD, Catalan N. Systemic lidocaine silences ectopic neuroma and DRG discharge without blocking nerve conduction. Pain 1992;48:261-268.

37. Ambrosio AF, Soares-Da-Silva P, Carvalho CM, Carvalho AP. Mechanisms of action of carbamazepine and its derivatives, oxcarbazepine, BIA 2-093, and BIA 2-024. Neurochem Res 2002; 27:121-130.

38. Tecoma ES. Oxcarbazepine. Epilepsia 1999;40 Suppl 5:S37-46.

39. Dogra S, Beydoun S, Mazzola J, Hopwood M, Wan Y. Oxcarbazepine in painful diabetic neuropathy: a randomized, placebocontrolled study. Eur J Pain 2005;9:543-554.

40. Grosskopf J, Mazzola J, Wan Y, Hopwood M. A randomized, placebo-controlled study of oxcarbazepine in painful diabetic neuropathy. Acta Neurol Scand 2006;114:177-180.

41. Errington AC, Stohr T, Heers C, Lees G. The investigational anticonvulsant lacosamide selectively enhances slow inactivation of voltage-gated sodium channels. Mol Pharmacol 2008;73:157169.

42. Wallace MS, Rowbotham M, Bennett GJ, Jensen TS, Pladna R, Quessy S. A multicenter, double-blind, randomized, placebo-controlled crossover evaluation of a short course of 4030W92 in patients with chronic neuropathic pain. J Pain 2002;3:227-233.

43. Hagen NA, du Souich P, Lapointe B, et al. Tetrodotoxin for moderate to severe cancer pain: a randomized, double blind, parallel design multicenter study. J Pain Symptom Manage 2008; 35:420-429.

44. Bach FW, Jensen TS, Kastrup J, Stigsby B, Dejgard A. The effect of intravenous lidocaine on nociceptive processing in diabetic neuropathy. Pain 1990;40:29-34. 
45. Ragsdale DS, McPhee JC, Scheuer T, Catterall WA. Common molecular determinants of local anesthetic, antiarrhythmic, and anticonvulsant block of voltage-gated $\mathrm{Na}+$ channels. Proc Natl Acad Sci U S A 1996;93:9270-9275.

46. Wagner LE, 2nd, Eaton M, Sabnis SS, Gingrich KJ. Meperidine and lidocaine block of recombinant voltage-dependent $\mathrm{Na}+$ channels: evidence that meperidine is a local anesthetic. Anesthesiology 1999;91:1481-1490.

47. Wagner LE, 2nd, Gingrich KJ, Kulli JC, Yang J. Ketamine blockade of voltage-gated sodium channels: evidence for a shared receptor site with local anesthetics. Anesthesiology 2001;95: $1406-1413$.

48. Wang GK, Russell C, Wang SY. State-dependent block of voltage-gated $\mathrm{Na}+$ channels by amitriptyline via the local anesthetic receptor and its implication for neuropathic pain. Pain 2004;110: $166-174$.

49. Yarov-Yarovoy V, Brown J, Sharp EM, Clare JJ, Scheuer T, Catterall WA. Molecular determinants of voltage-dependent gating and binding of pore-blocking drugs in transmembrane segment IIIS6 of the $\mathrm{Na}(+)$ channel alpha subunit. J Biol Chem 2001;276:20-27.

50. Starmer CF, Grant AO, Strauss HC. Mechanisms of use-dependent block of sodium channels in excitable membranes by local anesthetics. Biophys J 1984;46:15-27.

51. Schwarz W, Palade PT, Hille B. Local anesthetics. Effect of $\mathrm{pH}$ on use-dependent block of sodium channels in frog muscle. Biophys J 1977;20:343-368.

52. Courtney KR. Mechanism of frequency-dependent inhibition of sodium currents in frog myelinated nerve by the lidocaine derivative GEA. J Pharmacol Exp Ther 1975;195:225-236.

53. Hille B. Local anesthetics: hydrophilic and hydrophobic pathways for the drug-receptor reaction. J Gen Physiol 1977;69:497515 .

54. Hondeghem LM, Katzung BG. Antiarrhythmic agents: the modulated receptor mechanism of action of sodium and calcium channel-blocking drugs. Annu Rev Pharmacol Toxicol 1984;24:387423.

55. Catterall WA, Goldin AL, Waxman SG. International Union of Pharmacology. XXXIX. Compendium of voltage-gated ion channels: sodium channels. Pharmacol Rev 2003;55:575-578.

56. Catterall WA, Goldin AL, Waxman SG. International Union of Pharmacology. XLVII. Nomenclature and Structure-Function Relationships of Voltage-Gated Sodium Channels. Pharmacol Rev 2005;57:397-409.

57. Catterall WA, Cestele S, Yarov-Yarovoy V, Yu FH, Konoki K, Scheuer T. Voltage-gated ion channels and gating modifier toxins. Toxicon 2007;49:124-141.

58. Bosmans F, Tytgat J. Voltage-gated sodium channel modulation by scorpion alpha-toxins. Toxicon 2007;49:142-158.

59. Wang J, Ou SW, Wang YJ, Kameyama M, Kameyama A, Zong ZH. Analysis of four novel variants of Nav1.5/SCN5A cloned from the brain. Neurosci Res 2009.

60. Ragsdale DS. How do mutant Nav1.1 sodium channels cause epilepsy? Brain Res Rev 2008;58:149-159.

61. Vahedi K, Depienne C, Le Fort D, et al. Elicited repetitive daily blindness: a new phenotype associated with hemiplegic migraine and SCN1A mutations. Neurology 2009;72:1178-1183.

62. Scalmani P, Rusconi R, Armatura E, et al. Effects in neocortical neurons of mutations of the $\mathrm{Na}(\mathrm{v}) 1.2 \mathrm{Na}+$ channel causing benign familial neonatal-infantile seizures. J Neurosci 2006;26: 10100-10109.

63. Colosimo E, Gambardella A, Mantegazza M, et al. Electroclinical features of a family with simple febrile seizures and temporal lobe epilepsy associated with SCN1A loss-of-function mutation. Epilepsia 2007;48:1691-1696.

64. Fujiwara T. Clinical spectrum of mutations in SCN1A gene: severe myoclonic epilepsy in infancy and related epilepsies. Epilepsy Res 2006;70 Suppl 1:S223-230.

65. Fujiwara T, Sugawara T, Mazaki-Miyazaki E, et al. Mutations of sodium channel alpha subunit type 1 (SCN1A) in intractable childhood epilepsies with frequent generalized tonic-clonic seizures. Brain 2003;126:531-546.
66. Lossin C. A catalog of SCN1A variants. Brain Dev 2009;31:114130.

67. Lossin C, Rhodes TH, Desai RR, et al. Epilepsy-associated dysfunction in the voltage-gated neuronal sodium channel SCN1A. J Neurosci 2003;23:11289-11295.

68. Mantegazza M, Gambardella A, Rusconi R, et al. Identification of an Nav1.1 sodium channel (SCN1A) loss-of-function mutation associated with familial simple febrile seizures. Proc Natl Acad Sci U S A 2005;102:18177-18182.

69. Meisler MH, Kearney JA. Sodium channel mutations in epilepsy and other neurological disorders. J Clin Invest 2005;115:20102017.

70. Sugawara T, Mazaki-Miyazaki E, Fukushima K, et al. Frequent mutations of SCN1A in severe myoclonic epilepsy in infancy. Neurology 2002;58:1122-1124.

71. Vanoye CG, Lossin C, Rhodes TH, George AL, Jr. Singlechannel properties of human NaV1.1 and mechanism of channel dysfunction in SCN1A-associated epilepsy. J Gen Physiol 2006;127:1-14.

72. Jurkat-Rott K, Lehmann-Horn F. Genotype-phenotype correlation and therapeutic rationale in hyperkalemic periodic paralysis. Neurotherapeutics 2007;4:216-224.

73. Lehmann-Horn F, Jurkat-Rott K, Rudel R. Periodic paralysis: understanding channelopathies. Curr Neurol Neurosci Rep 2002; 2:61-69.

74. Sternberg D, Maisonobe T, Jurkat-Rott K, et al. Hypokalaemic periodic paralysis type 2 caused by mutations at codon 672 in the muscle sodium channel gene SCN4A. Brain 2001;124:10911099.

75. Rogart RB, Cribbs LL, Muglia LK, Kephart DD, Kaiser MW. Molecular cloning of a putative tetrodotoxin-resistant rat heart $\mathrm{Na}+$ channel isoform. Proc Natl Acad Sci U S A 1989;86:81708174.

76. Remme CA, Wilde AA, Bezzina CR. Cardiac sodium channel overlap syndromes: different faces of SCN5A mutations. Trends Cardiovasc Med 2008;18:78-87.

77. Zimmer T, Surber R. SCN5A channelopathies-an update on mutations and mechanisms. Prog Biophys Mol Biol 2008;98:120136.

78. McKinney BC, Chow CY, Meisler MH, Murphy GG. Exaggerated emotional behavior in mice heterozygous null for the sodium channel Scn8a (Nav1.6). Genes Brain Behav 2008;7:629-638.

79. Chen YH, Dale TJ, Romanos MA, Whitaker WR, Xie XM, Clare JJ. Cloning, distribution and functional analysis of the type III sodium channel from human brain. Eur J Neurosci 2000;12: 4281-4289.

80. Black JA, Liu S, Tanaka M, Cummins TR, Waxman SG. Changes in the expression of tetrodotoxin-sensitive sodium channels within dorsal root ganglia neurons in inflammatory pain. Pain 2004;108:237-247.

81. Dib-Hajj SD, Fjell J, Cummins TR, et al. Plasticity of sodium channel expression in DRG neurons in the chronic constriction injury model of neuropathic pain. Pain 1999;83:591-600.

82. Waxman SG, Kocsis JD, Black JA. Type III sodium channel mRNA is expressed in embryonic but not adult spinal sensory neurons, and is reexpressed following axotomy. J Neurophysiol 1994;72:466-470.

83. Cummins TR, Waxman SG. Downregulation of tetrodotoxinresistant sodium currents and upregulation of a rapidly repriming tetrodotoxin-sensitive sodium current in small spinal sensory neurons after nerve injury. J Neurosci 1997;17:3503-3514.

84. Fukuoka T, Kobayashi K, Yamanaka H, Obata K, Dai Y, Noguchi K. Comparative study of the distribution of the alpha-subunits of voltage-gated sodium channels in normal and axotomized rat dorsal root ganglion neurons. J Comp Neurol 2008;510:188-206.

85. Zhao P, Waxman SG, Hains BC. Sodium channel expression in the ventral posterolateral nucleus of the thalamus after peripheral nerve injury. Mol Pain 2006;2:27.

86. Guo F, Yu N, Cai JQ, et al. Voltage-gated sodium channel Nav1.1, Nav1.3 and beta1 subunit were up-regulated in the hippocampus of spontaneously epileptic rat. Brain Res Bull 2008; 75:179-187.

87. Bartolomei F, Gastaldi M, Massacrier A, Planells R, Nicolas S, 
Cau P. Changes in the mRNAs encoding subtypes I, II and III sodium channel alpha subunits following kainate-induced seizures in rat brain. J Neurocytol 1997;26:667-678.

88. Nassar MA, Baker MD, Levato A, et al. Nerve injury induces robust allodynia and ectopic discharges in Nav1.3 null mutant mice. Mol Pain 2006;2:33.

89. Hains BC, Saab CY, Klein JP, Craner MJ, Waxman SG. Altered sodium channel expression in second-order spinal sensory neurons contributes to pain after peripheral nerve injury. J Neurosci 2004;24:4832-4839.

90. Lindia JA, Kohler MG, Martin WJ, Abbadie C. Relationship between sodium channel NaV1.3 expression and neuropathic pain behavior in rats. Pain 2005;117:145-153.

91. Sangameswaran L, Fish LM, Koch BD, et al. A novel tetrodotoxinsensitive, voltage-gated sodium channel expressed in rat and human dorsal root ganglia. J Biol Chem 1997;272:14805-14809.

92. Toledo-Aral JJ, Moss BL, He ZJ, et al. Identification of PN1, a predominant voltage-dependent sodium channel expressed principally in peripheral neurons. Proc Natl Acad Sci U S A 1997; 94:1527-1532.

93. Thakor DK, Lin A, Matsuka Y, et al. Increased peripheral nerve excitability and local NaV1.8 mRNA up-regulation in painful neuropathy. Mol Pain 2009;5:14.

94. Kretschmer T, Happel LT, England JD, et al. Accumulation of PN1 and PN3 sodium channels in painful human neuroma-evidence from immunocytochemistry. Acta Neurochir (Wien) 2002; 144:803-810; discussion 810.

95. Cummins TR, Howe JR, Waxman SG. Slow closed-state inactivation: a novel mechanism underlying ramp currents in cells expressing the hNE/PN1 sodium channel. J Neurosci 1998;18: 9607-9619.

96. Nassar MA, Stirling LC, Forlani G, et al. Nociceptor-specific gene deletion reveals a major role for Nav1.7 (PN1) in acute and inflammatory pain. Proc Natl Acad Sci U S A 2004;101:1270612711.

97. Nassar MA, Levato A, Stirling LC, Wood JN. Neuropathic pain develops normally in mice lacking both Nav1.7 and Nav1.8. Mol Pain 2005;1:24.

98. Djouhri L, Fang X, Okuse K, Wood JN, Berry CM, Lawson SN. The TTX-resistant sodium channel Nav1.8 (SNS/PN3): expression and correlation with membrane properties in rat nociceptive primary afferent neurons. J Physiol 2003;550:739-752.

99. Devor M. Ectopic discharge in Abeta afferents as a source of neuropathic pain. Exp Brain Res 2009;196:115-128.

100. Fertleman CR, Baker MD, Parker KA, et al. SCN9A mutations in paroxysmal extreme pain disorder: allelic variants underlie distinct channel defects and phenotypes. Neuron 2006;52:767-774.

101. Yang Y, Wang Y, Li S, et al. Mutations in SCN9A, encoding a sodium channel alpha subunit, in patients with primary erythermalgia. J Med Genet 2004;41:171-174.

102. Cox JJ, Reimann F, Nicholas AK, et al. An SCN9A channelopathy causes congenital inability to experience pain. Nature 2006; 444:894-898.

103. Goldberg YP, MacFarlane J, MacDonald ML, et al. Loss-offunction mutations in the Nav1.7 gene underlie congenital indifference to pain in multiple human populations. Clin Genet 2007; 71:311-319.

104. Nilsen KB, Nicholas AK, Woods CG, Mellgren SI, Nebuchennykh M, Aasly J. Two novel SCN9A mutations causing insensitivity to pain. Pain 2009;143:155-158.

105. Ahmad S, Dahllund L, Eriksson AB, et al. A stop codon mutation in SCN9A causes lack of pain sensation. Hum Mol Genet 2007; 16:2114-2121.

106. Drenth JP, Waxman SG. Mutations in sodium-channel gene SCN9A cause a spectrum of human genetic pain disorders. J Clin Invest 2007;117:3603-3609.

107. Cheng X, Dib-Hajj SD, Tyrrell L, Waxman SG. Mutation I136V alters electrophysiological properties of the $\mathrm{Na}(\mathrm{v}) 1.7$ channel in a family with onset of erythromelalgia in the second decade. Mol Pain 2008;4:1.

108. Choi JS, Dib-Hajj SD, Waxman SG. Inherited erythermalgia: limb pain from an S4 charge-neutral Na channelopathy. Neurology 2006;67:1563-1567.
109. Cummins TR, Dib-Hajj SD, Waxman SG. Electrophysiological properties of mutant Nav1.7 sodium channels in a painful inherited neuropathy. J Neurosci 2004;24:8232-8236.

110. Dib-Hajj SD, Rush AM, Cummins TR, et al. Gain-of-function mutation in Nav1.7 in familial erythromelalgia induces bursting of sensory neurons. Brain 2005;128:1847-1854.

111. Han C, Rush AM, Dib-Hajj SD, et al. Sporadic onset of erythermalgia: a gain-of-function mutation in Nav1.7. Ann Neurol 2006;59:553-558.

112. Harty TP, Dib-Hajj SD, Tyrrell L, et al. Na(V)1.7 mutant A863P in erythromelalgia: effects of altered activation and steady-state inactivation on excitability of nociceptive dorsal root ganglion neurons. J Neurosci 2006;26:12566-12575.

113. Lampert A, Dib-Hajj SD, Tyrrell L, Waxman SG. Size matters: Erythromelalgia mutation S241T in Nav1.7 alters channel gating. J Biol Chem 2006;281:36029-36035.

114. Sheets PL, Jackson JO, 2nd, Waxman SG, Dib-Hajj SD, Cummins TR. A Nav1.7 channel mutation associated with hereditary erythromelalgia contributes to neuronal hyperexcitability and displays reduced lidocaine sensitivity. J Physiol 2007;581:1019_ 1031.

115. Dib-Hajj SD, Yang Y, Waxman SG. Genetics and molecular pathophysiology of $\mathrm{Na}(\mathrm{v}) 1.7$-related pain syndromes. Adv Genet 2008;63:85-110.

116. Jarecki BW, Sheets PL, Jackson IIJO, Cummins TR. Paroxysmal Extreme Pain Disorder mutations within the D3/S4-S5 Linker of Nav1.7 cause moderate destabilization of fast-inactivation. J Physiol 2008:jphysiol.2008.154906.

117. Zimmermann K, Leffler A, Babes A, et al. Sensory neuron sodium channel Nav1.8 is essential for pain at low temperatures. Nature 2007;447:855-858.

118. Abrahamsen B, Zhao J, Asante CO, et al. The Cell and Molecular Basis of Mechanical, Cold, and Inflammatory Pain. Science 2008; 321:702-705.

119. Okuse K, Chaplan SR, McMahon SB, et al. Regulation of expression of the sensory neuron-specific sodium channel SNS in inflammatory and neuropathic pain. Mol Cell Neurosci 1997;10: 196-207.

120. Decosterd I, Ji RR, Abdi S, Tate S, Woolf CJ. The pattern of expression of the voltage-gated sodium channels $\mathrm{Na}(\mathrm{v}) 1.8$ and $\mathrm{Na}(\mathrm{v}) 1.9$ does not change in uninjured primary sensory neurons in experimental neuropathic pain models. Pain 2002;96:269-277.

121. Novakovic SD, Tzoumaka E, McGivern JG, et al. Distribution of the tetrodotoxin-resistant sodium channel PN3 in rat sensory neurons in normal and neuropathic conditions. J Neurosci 1998;18: $2174-2187$.

122. Dong XW, Goregoaker S, Engler H, et al. Small interfering RNA-mediated selective knockdown of $\mathrm{Na}(\mathrm{V}) 1.8$ tetrodotoxinresistant sodium channel reverses mechanical allodynia in neuropathic rats. Neuroscience 2007;146:812-821.

123. Joshi SK, Mikusa JP, Hernandez G, et al. Involvement of the TTX-resistant sodium channel Nav 1.8 in inflammatory and neuropathic, but not post-operative, pain states. Pain 2006; 123:75-82.

124. Lai J, Gold MS, Kim CS, et al. Inhibition of neuropathic pain by decreased expression of the tetrodotoxin-resistant sodium channel, NaV1.8. Pain 2002;95:143-152.

125. Roza C, Laird JM, Souslova V, Wood JN, Cervero F. The tetrodotoxin-resistant $\mathrm{Na}+$ channel Nav1.8 is essential for the expression of spontaneous activity in damaged sensory axons of mice. J Physiol 2003;550:921-926.

126. Cummins TR, Dib-Hajj SD, Black JA, Akopian AN, Wood JN, Waxman SG. A novel persistent tetrodotoxin-resistant sodium current in SNS-null and wild-type small primary sensory neurons. J Neurosci 1999;19:RC43.

127. Dib-Hajj SD, Tyrrell L, Cummins TR, Black JA, Wood PM, Waxman SG. Two tetrodotoxin-resistant sodium channels in human dorsal root ganglion neurons. FEBS Lett 1999;462:117-120.

128. Dib-Hajj S, Black JA, Cummins TR, Waxman SG. NaN/Nav1.9: a sodium channel with unique properties. Trends Neurosci 2002; 25:253-259.

129. Dib-Hajj SD, Tyrrell L, Black JA, Waxman SG. NaN, a novel voltage-gated Na channel, is expressed preferentially in periph- 
eral sensory neurons and down-regulated after axotomy. Proc Natl Acad Sci U S A 1998;95:8963-8968.

130. Tate S, Benn S, Hick C, et al. Two sodium channels contribute to the TTX-R sodium current in primary sensory neurons. Nat Neurosci 1998;1:653-655.

131. Porreca F, Lai J, Bian D, et al. A comparison of the potential role of the tetrodotoxin-insensitive sodium channels, PN3/SNS and NaN/SNS2, in rat models of chronic pain. Proc Natl Acad Sci U S A 1999;96:7640-7644.

132. Priest BT, Murphy BA, Lindia JA, et al. Contribution of the tetrodotoxin-resistant voltage-gated sodium channel NaV1.9 to sensory transmission and nociceptive behavior. Proc Natl Acad Sci U S A 2005;102:9382-9387.

133. Smith ESJ, Momin A. Persistent pain: the contribution of NaV1.9. J Physiol 2008:jphysiol.2008.152520.

134. Jarvis MF, Honore P, Shieh CC, et al. A-803467, a potent and selective Nav1.8 sodium channel blocker, attenuates neuropathic and inflammatory pain in the rat. Proc Natl Acad Sci U S A 2007;104:8520-8525.

135. Kort ME, Drizin I, Gregg RJ, et al. Discovery and biological evaluation of 5-aryl-2-furfuramides, potent and selective blockers of the Nav1.8 sodium channel with efficacy in models of neuropathic and inflammatory pain. J Med Chem 2008;51: 407-416.

136. McGaraughty S, Chu KL, Scanio MJ, Kort ME, Faltynek CR, Jarvis MF. A selective Nav1.8 sodium channel blocker, A-803467 [5-(4-chlorophenyl-N-(3,5-dimethoxyphenyl)furan-2carboxamide], attenuates spinal neuronal activity in neuropathic rats. J Pharmacol Exp Ther 2008;324:1204-1211.

137. Felix JP, Williams BS, Priest BT, et al. Functional assay of voltage-gated sodium channels using membrane potential-sensitive dyes. Assay Drug Dev Technol 2004;2:260-268.

138. Hoyt SB, London C, Gorin D, et al. Discovery of a novel class of benzazepinone $\mathrm{Na}(\mathrm{v}) 1.7$ blockers: potential treatments for neuropathic pain. Bioorg Med Chem Lett 2007;17:4630-4634.

139. Hoyt SB, London C, Ok H, et al. Benzazepinone Na(v) 1.7 blockers: Potential treatments for neuropathic pain. Bioorg Med Chem Lett 2007.

140. Williams BS, Felix JP, Priest BT, et al. Characterization of a new class of potent inhibitors of the voltage-gated sodium channel Nav1.7. Biochemistry 2007;46:14693-14703.

141. London C, Hoyt SB, Parsons WH, et al. Imidazopyridines: a novel class of hNav1.7 channel blockers. Bioorg Med Chem Lett 2008; 18:1696-1701.

142. Liu CJ, Priest BT, Bugianesi RM, et al. A high-capacity membrane potential FRET-based assay for NaV1.8 channels. Assay Drug Dev Technol 2006;4:37-48.

143. Trivedi S, Dekermendjian K, Julien R, et al. Cellular HTS Assays for Pharmacological Characterization of $\mathrm{Na}(\mathrm{V}) 1.7$ Modulators. Assay Drug Dev Technol 2007.

144. Vickery RG, Amagasu SM, Chang R, et al. Comparison of the pharmacological properties of rat $\mathrm{Na}(\mathrm{V}) 1.8$ with rat $\mathrm{Na}(\mathrm{V}) 1.2 \mathrm{a}$ and human $\mathrm{Na}(\mathrm{V}) 1.5$ voltage-gated sodium channel subtypes using a membrane potential sensitive dye and FLIPR. Receptors Channels 2004;10:11-23.

145. Benjamin ER, Pruthi F, Olanrewaju S, et al. State-dependent compound inhibition of Nav1.2 sodium channels using the FLIPR Vm dye: on-target and off-target effects of diverse pharmacological agents. J Biomol Screen 2006;11:29-39.

146. Bhattacharya A, Wang Q, Wu N, Chaplan SR, Wickenden AD. Assay dependent activity of the sodium channel gating modifier protoxin-I: implications for sodium channel drug discovery. In: Experimental Biology; 2009; New Orleans, LA, 2009.

147. Middleton RE, Warren VA, Kraus RL, et al. Two tarantula peptides inhibit activation of multiple sodium channels. Biochemistry 2002;41:14734-14747.

148. Castle N, Printzenhoff D, Zellmer S, Antonio B, Wickenden A, Silvia C. Sodium channel inhibitor drug discovery using automated high throughput electrophysiology platforms. Comb Chem High Throughput Screen 2009;12:107-122.

149. Schmalhofer W, Calhoun J, Burrows R, et al. ProTx-II, a selective inhibitor of NaV1.7 sodium channels, blocks action potential propagation in nociceptors. Mol Pharmacol 2008:mol.108.047670.
150. Escoubas P, Bosmans F. Spider peptide toxins as leads for drug development. Expert Opinion on Drug Discovery 2007;2:823-835.

151. Xiao Y, Bingham JP, Zhu W, Moczydlowski E, Liang S, Cummins TR. Tarantula huwentoxin-IV inhibits neuronal sodium channels by binding to receptor site 4 and trapping the domain ii voltage sensor in the closed configuration. J Biol Chem 2008; 283:27300-27313.

152. Bosmans F, Martin-Eauclaire MF, Swartz KJ. Deconstructing voltage sensor function and pharmacology in sodium channels. Nature 2008;456:202-208.

153. Sokolov S, Kraus RL, Scheuer T, Catterall WA. Inhibition of Sodium Channel Gating by Trapping the Domain II Voltage Sensor with Protoxin II. Mol Pharmacol 2008;73:1020-1028.

154. Smith JJ, Cummins TR, Alphy S, Blumenthal KM. Molecular Interactions of the Gating Modifier Toxin ProTx-II with Nav1.5: Implied existence of a novel toxin binding site coupled to activation. J Biol Chem 2007;282:12687-12697.

155. Dib-Hajj SD, Binshtok AM, Cummins TR, Jarvis MF, Samad T, Zimmermann K. Voltage-gated sodium channels in pain states: Role in pathophysiology and targets for treatment. Brain Res Rev 2009;60:65-83.

156. Waxman SG. Channel, neuronal and clinical function in sodium channelopathies: from genotype to phenotype. Nat Neurosci 2007; 10:405-409.

157. Cummins TR, Rush AM. Voltage-gated sodium channel blockers for the treatment of neuropathic pain. Expert Rev Neurother 2007;7:1597-1612.

158. Cummins TR, Sheets PL, Waxman SG. The roles of sodium channels in nociception: Implications for mechanisms of pain. Pain 2007;131:243-257.

159. Wood JN, Boorman J. Voltage-gated sodium channel blockers; target validation and therapeutic potential. Curr Top Med Chem 2005;5:529-537.

160. Wood JN, Boorman JP, Okuse K, Baker MD. Voltage-gated sodium channels and pain pathways. J Neurobiol 2004;61:55-71.

161. England S. Voltage-gated sodium channels: the search for subtype-selective analgesics. Expert Opinion on Investigational Drugs 2008;17:1849-1864.

162. Momin A, Wood JN. Sensory neuron voltage-gated sodium channels as analgesic drug targets. Curr Opin Neurobiol 2008;18:383388.

163. Priest BT, Kaczorowski GJ. Blocking sodium channels to treat neuropathic pain. Expert Opin Ther Targets 2007;11:291-306.

164. Hargus NJ, Patel MK. Voltage-gated Na+ channels in neuropathic pain. Expert Opinion on Investigational Drugs 2007;16: 635-646.

165. Catterall WA. From ionic currents to molecular mechanisms: the structure and function of voltage-gated sodium channels. Neuron 2000;26:13-25.

166. Kalso E, Tasmuth T, Neuvonen PJ. Amitriptyline effectively relieves neuropathic pain following treatment of breast cancer. Pain 1996;64:293-302.

167. Kautio AL, Haanpaa M, Saarto T, Kalso E. Amitriptyline in the treatment of chemotherapy-induced neuropathic symptoms. J Pain Symptom Manage 2008;35:31-39.

168. Campbell FG, Graham JG, Zilkha KJ. Clinical trial of carbazepine (tegretol) in trigeminal neuralgia. J Neurol Neurosurg Psychiatry 1966;29:265-267.

169. Killian JM, Fromm GH. Carbamazepine in the treatment of neuralgia. Use of side effects. Arch Neurol 1968;19:129-136.

170. Rull JA, Quibrera R, Gonzalez-Millan H, Lozano Castaneda O. Symptomatic treatment of peripheral diabetic neuropathy with carbamazepine (Tegretol): double blind crossover trial. Diabetologia 1969;5:215-218.

171. Harke H, Gretenkort P, Ladleif HU, Rahman S, Harke O. The response of neuropathic pain and pain in complex regional pain syndrome I to carbamazepine and sustained-release morphine in patients pretreated with spinal cord stimulation: a double-blinded randomized study. Anesth Analg 2001;92:488-495.

172. Kishore-Kumar R, Max MB, Schafer SC, et al. Desipramine relieves postherpetic neuralgia. Clin Pharmacol Ther 1990;47: 305-312. 
173. Max MB, Kishore-Kumar R, Schafer SC, et al. Efficacy of desipramine in painful diabetic neuropathy: a placebo-controlled trial. Pain 1991;45:3-9; discussion 1-2.

174. Goldstein DJ, Lu Y, Detke MJ, Lee TC, Iyengar S. Duloxetine vs. placebo in patients with painful diabetic neuropathy. Pain 2005; 116:109-118.

175. Raskin J, Pritchett YL, Wang F, et al. A double-blind, randomized multicenter trial comparing duloxetine with placebo in the management of diabetic peripheral neuropathic pain. Pain Med 2005;6:346-356.

176. Wernicke JF, Pritchett YL, D'Souza DN, et al. A randomized controlled trial of duloxetine in diabetic peripheral neuropathic pain. Neurology 2006;67:1411-1420.

177. Rauck RL, Shaibani A, Biton V, Simpson J, Koch B. Lacosamide in painful diabetic peripheral neuropathy: a phase 2 double-blind placebo-controlled study. Clin J Pain 2007;23:150-158.

178. Shaibani A, Fares S, Selam JL, et al. Lacosamide in Painful Diabetic Neuropathy: An 18-Week Double-Blind Placebo-Controlled Trial. J Pain 2009.

179. Wymer JP, Simpson J, Sen D, Bongardt S. Efficacy and safety of lacosamide in diabetic neuropathic pain: an 18-week double-blind placebo-controlled trial of fixed-dose regimens. Clin J Pain 2009; 25:376-385.

180. Zakrzewska JM, Chaudhry Z, Nurmikko TJ, Patton DW, Mullens EL. Lamotrigine (lamictal) in refractory trigeminal neuralgia: results from a double-blind placebo controlled crossover trial. Pain 1997;73:223-230.

181. McCleane G. $200 \mathrm{mg}$ daily of lamotrigine has no analgesic effect in neuropathic pain: a randomised, double-blind, placebo controlled trial. Pain 1999;83:105-107.

182. Eisenberg E, Lurie Y, Braker C, Daoud D, Ishay A. Lamotrigine reduces painful diabetic neuropathy: a randomized, controlled study. Neurology 2001;57:505-509.

183. Vestergaard K, Andersen G, Gottrup H, Kristensen BT, Jensen TS. Lamotrigine for central poststroke pain: a randomized controlled trial. Neurology 2001;56:184-190.

184. Finnerup NB, Sindrup SH, Bach FW, Johannesen IL, Jensen TS. Lamotrigine in spinal cord injury pain: a randomized controlled trial. Pain 2002;96:375-383.

185. Simpson DM, McArthur JC, Olney R, et al. Lamotrigine for HIV-associated painful sensory neuropathies: a placebo-controlled trial. Neurology 2003;60:1508-1514.

186. Rao RD, Flynn PJ, Sloan JA, et al. Efficacy of lamotrigine in the management of chemotherapy-induced peripheral neuropathy: a phase 3 randomized, double-blind, placebo-controlled trial, N01C3. Cancer 2008;112:2802-2808.

187. Kastrup J, Bach FW, Petersen P, et al. Lidocaine treatment of painful diabetic neuropathy and endogenous opioid peptides in plasma. Clin J Pain 1989;5:239-244.

188. Ellemann K, Sjogren P, Banning AM, Jensen TS, Smith T, Geertsen $P$. Trial of intravenous lidocaine on painful neuropathy in cancer patients. Clin J Pain 1989;5:291-294.

189. Rowbotham MC, Reisner-Keller LA, Fields HL. Both intravenous lidocaine and morphine reduce the pain of postherpetic neuralgia. Neurology 1991;41:1024-1028.

190. Bruera E, Ripamonti C, Brenneis C, Macmillan K, Hanson J. A randomized double-blind crossover trial of intravenous lidocaine in the treatment of neuropathic cancer pain. J Pain Symptom Manage 1992; 7:138-140.

191. Medrik-Goldberg T, Lifschitz D, Pud D, Adler R, Eisenberg E. Intravenous lidocaine, amantadine, and placebo in the treatment of sciatica: a double-blind, randomized, controlled study. Reg Anesth Pain Med 1999;24:534-540.

192. Wallace MS, Ridgeway BM, Leung AY, Gerayli A, Yaksh TL. Concentration-effect relationship of intravenous lidocaine on the allodynia of complex regional pain syndrome types I and II. Anesthesiology 2000;92:75-83.

193. Attal N, Gaude V, Brasseur L, et al. Intravenous lidocaine in central pain: a double-blind, placebo-controlled, psychophysical study. Neurology 2000;54:564-574.

194. Finnerup NB, Biering-Sorensen F, Johannesen IL, et al. Intravenous lidocaine relieves spinal cord injury pain: a randomized controlled trial. Anesthesiology 2005;102:1023-1030.

195. Tremont-Lukats IW, Hutson PR, Backonja MM. A randomized, double-masked, placebo-controlled pilot trial of extended IV lidocaine infusion for relief of ongoing neuropathic pain. Clin J Pain 2006;22:266-271.

196. Backonja M, Gombar KA. Response of central pain syndromes to intravenous lidocaine. J Pain Symptom Manage 1992;7:172-178.

197. Attal N, Rouaud J, Brasseur L, Chauvin M, Bouhassira D. Systemic lidocaine in pain due to peripheral nerve injury and predictors of response. Neurology 2004;62:218-225.

198. Sakurai M, Kanazawa I. Positive symptoms in multiple sclerosis: their treatment with sodium channel blockers, lidocaine and mexiletine. J Neurol Sci 1999;162:162-168.

199. Chabal C, Jacobson L, Russell LC, Burchiel KJ. Pain responses to perineuromal injection of normal saline, gallamine, and lidocaine in humans. Pain 1989;36:321-325.

200. Chabal C, Jacobson L, Mariano A, Chaney E, Britell CW. The use of oral mexiletine for the treatment of pain after peripheral nerve injury. Anesthesiology 1992;76:513-517.

201. Stracke H, Meyer UE, Schumacher HE, Federlin K. Mexiletine in the treatment of diabetic neuropathy. Diabetes Care 1992;15: $1550-1555$

202. Chiou-Tan FY, Tuel SM, Johnson JC, Priebe MM, Hirsh DD, Strayer JR. Effect of mexiletine on spinal cord injury dysesthetic pain. Am J Phys Med Rehabil 1996;75:84-87.

203. Oskarsson P, Ljunggren JG, Lins PE. Efficacy and safety of mexiletine in the treatment of painful diabetic neuropathy. The Mexiletine Study Group. Diabetes Care 1997;20:1594-1597.

204. Wright JM, Oki JC, Graves L, 3rd.Mexiletine in the symptomatic treatment of diabetic peripheral neuropathy. Ann Pharmacother 1997:31:29-34.

205. Wallace MS, Magnuson S, Ridgeway B. Efficacy of oral mexiletine for neuropathic pain with allodynia: a double-blind, placebo-controlled, crossover study. Reg Anesth Pain Med 2000;25:459-467.

206. Saudek CD, Werns S, Reidenberg MM. Phenytoin in the treatment of diabetic symmetrical polyneuropathy. Clin Pharmacol Ther 1977;22:196-199.

207. Chadda VS, Mathur MS. Double blind study of the effects of diphenylhydantoin sodium on diabetic neuropathy. J Assoc Physicians India 1978;26:403-406.

208. Galer BS, Twilling LL, Harle J, Cluff RS, Friedman E, Rowbotham MC. Lack of efficacy of riluzole in the treatment of peripheral neuropathic pain conditions. Neurology 2000;55:971-975. 